JOBNAME: No Job Name PAGE: 1 SESS: 11 OUTPUT: Fri May 29 17:57:38 2015 SUM: 7D07211C

/Xpp84_Wiley/wiley_journal_N-O/OJOA/ojoa_v34_i3/1ojoa_12056

\begin{tabular}{|l|c|}
\hline \multicolumn{2}{|c|}{ Toppan Best-set Premedia Limited } \\
\hline Journal Code: OJOA & Proofreader: Mony \\
\hline Article No: OJOA12056 & Delivery date: 29 May 2015 \\
\hline Page Extent: 27 & \\
\hline
\end{tabular}

\title{
BETYLMANIA? - SMALL STANDING STONES AND THE MEGALITHS OF SOUTH-WEST BRITAIN
}

\begin{abstract}
Summary. This paper calls attention to a previously neglected element of the broad repertoire of monumental megalithic structures that characterize the later third and second millennia BC across the British Isles - extremely small standing stones. Despite their frequency and the complex arrangements and associations they embody, these miniliths are rarely recorded in detail and frequently marginalized to a generic background. As a result, they are largely absent from interpretative accounts. Drawing upon recent debates regarding materiality and monument form, alongside the results of excavations explicitly targeting tiny stone settings, the discussion argues that the phenomenon of raising and fixing small uprights was not only widespread and persistent, but sheds important light upon the beliefs and ideas driving monument construction during the later Neolithic and Bronze Ages.
\end{abstract}

\section{INTRODUCTION - THE USE OF SMALL STANDING STONES}

Slightly in front of the top layer of packing stones another sarsen was found lying on the chalk. It was quite definitely in its original position but could have served no practical purpose where it was. Indeed it gave the impression of having been deliberately placed where it was found. This is interesting since this stone did not in itself resemble a supporting or a packing stone, but in shape was of a pure B.1 form in miniature The writer is inclined to suggest that this may have been a betyl stone placed ... for some ritual purpose (Alexander Keiller, unpublished draft excavation report, writing of Stone 33 of Avebury's outer circle - the smallest of the surviving Avebury uprights (Smith 1965, 196)).

This discussion seeks better to understand a group of unique megalithic structures that have been recorded on the uplands of Exmoor in south-west Britain (Fig. 1). This is a group of monuments whose distinctiveness arises from the very small upright stones - miniliths - that are their defining characteristic. Central to this is a careful reconsideration of the role (and perceived importance) of very small stones in the construction and subsequent life of monuments in prehistory, situating the practices taking place on Exmoor within the British 
JOBNAME: No Job Name PAGE: 2 SESS: 11 OUTPUT: Fri May 29 17:57:38 2015 SUM: 1992C502

/Xpp84_Wiley/wiley_journal_N-O/OJOA/ojoa_v34_i3/1ojoa_12056

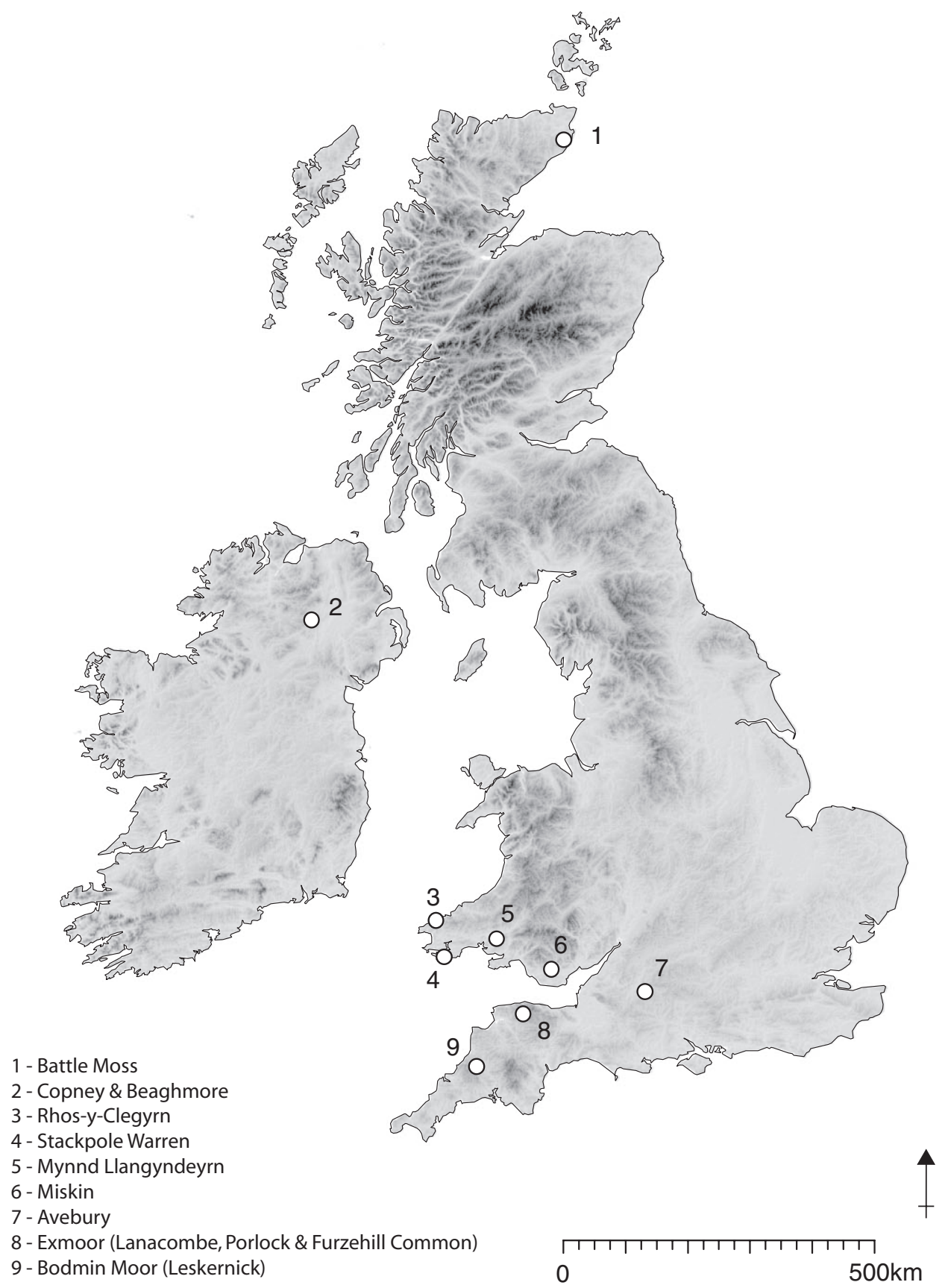

Figure 1

General location of the sites discussed in the text. 


\section{MARK GILLINGS}

Isles more broadly. As will become clear, far from being unique or unusual, tiny standing stones were a prominent element in a broad monumental repertoire that was actively drawn upon in a host of local, often highly contingent ways during the later third and second millennia BC. As to their relative invisibility in academic accounts, this, it is argued, is a consequence of the way in which we record stones, relegating smaller examples to the background in our interpretative accounts.

Rather than approaching the problem through the lens of the monument, the approach adopted here has been to work up from the detail of individual standing stones, treating the overall monumental form as a consequence rather than defining imperative. Arguing that we need to approach monuments not as coherent, planned structures but instead as motleys or assemblages - the results (or residues) left behind by a series of disparate imperatives and initiatives - is hardly new (Lucas 2012, 204; see Richards 2013 for a recent review). Neither is the notion that the wide (and often perplexing) range of monumental structures we encounter were the result of local expressions of what have been described as 'simple ideas' whose currency spanned the British Isles (Bradley 2007, 174). For example, in his discussion of the recumbent stone circles of north-east Scotland, Bradley has argued that individual monuments dynamically embodied a range of ideas and concepts 'that were current over a larger area during the Late Neolithic/Early Bronze Age. These might not have been conceived as architectural or structural devices, so much as the embodiment of certain beliefs' (2005, 113 ; 2011, 97). The latter could relate to the manipulation of certain materials, recurrent patterns of orientation, adherence to archetypal configurations such as the circle, or the metaphoric expression of underlying structuring principles such as 'wrapping' and enclosure (Richards 2013). That individual groups, separated in space and time, may have been drawing creatively upon a shared pool of concepts and ways-of-doing would certainly account for the presence across the British Isles of structures whose superficial similarities invite tidy classification, yet whose similarities begin to break down as soon as the detail is placed under scrutiny (Williams 1988, 54).

Taken together, these perspectives offer a productive way of considering monuments, which moves beyond the inherently reductive and generalizing tendencies that characterize more classificatory approaches. If monuments are dynamic expressions of a series of themes/motifs/ ideas that may not be explicit from the final form of the structure, then the archaeological project becomes one of identifying and charting these expressions and the relationships that were instantiated between them. The current paper seeks to build upon such debates through the development of four main arguments. The first is that the deployment of extremely small standing stones was a ubiquitous, yet hitherto unacknowledged, characteristic of the complex and varied range of monument types that had currency in the latter part of the third and throughout the second millennia BC. Second, the decision to erect miniliths represents precisely the kind of citation and creative manifestation of a shared idea identified by researchers such as Bradley; one that was played out in a host of regional, local and often highly contingent ways. Third, if the archaeological goal is to identify and characterize the beliefs made manifest in any given monument or group of such, it follows that we need to look carefully and critically at the activities involved in translating, expressing and materializing such ideas, for example the practices involved in raising, fixing and dismantling tiny uprights. Fourth, hampering such investigation at present is the lack of archaeological attention afforded to these features; as will be seen, small standing stones have been relegated to the background in our discussions when mentioned at all. 
JOBNAME: No Job Name PAGE: 4 SESS: 11 OUTPUT: Fri May 29 17:57:38 2015 SUM: 6B0CCF34

/Xpp84_Wiley/wiley_journal_N-O/OJOA/ojoa_v34_i3/1ojoa_12056

BETYLMANIA? - SMALL STANDING STONES AND THE MEGALITHS OF SOUTH-WEST BRITAIN

\section{THE EXMOOR MEGALITHS}

Despite its unique configurations of standing stones being noted as early as the 1607 edition of Camden's Britannia, with the exception of two academic overviews (Grinsell 1970; Riley and Wilson-North 2001) drawing attention to the richness, remarkable preservation and idiosyncratic character of its surviving prehistoric remains, there has been little in the way of detailed and critical analysis of Exmoor's Neolithic and Bronze Age archaeology (recent exceptions being Tilley 2010; Gillings et al. 2010). Instead, the tendency has been to assume that Exmoor followed essentially the same trajectory as the better studied granitic uplands of south-west Britain such as Dartmoor and Bodmin. Whilst Exmoor does contain the single and paired standing stones, circles and stone rows familiar from such areas, it is also home to a group of 59 megalithic structures known as 'settings' which appear to be unique. Frequently associated with small cairns, these comprise clusters of standing stones that take a variety of geometric (e.g. triangles, rectangles and quincunxes), quasi-geometric and apparently random forms (Fig. 2) (Riley and Wilson-North 2001, 27; Chanter and Worth 1905; 1906). Whilst the smaller settings are of the order of $10 \mathrm{~m}$ in maximum dimension, the larger examples can extend for up to $40 \mathrm{~m}$ (Quinnell and Dunn 1992). One characteristic that all of the settings share (along with the eight stone rows and two circles recorded on Exmoor) is the diminutive size of the component stones used in their construction, a feature that led Burl to playfully refer to them as 'minilithic' (Burl 1993, 88) (Fig. 3). Whilst it is tempting to attribute this to stone availability, citing the nongranitic geology of the moor and lack of ready-to-hand surface stone, sites such as the clapper bridge at Tarr Steps demonstrate that large stones are available, and traditional megaliths do exist on Exmoor such as the $3 \mathrm{~m}$ high Long Stone at Challacombe (Riley and Wilson-North 2001, 30). The preferential deployment of small stones seems to have been deliberate and it is this aspect of the Exmoor megaliths that I want to focus upon in the current discussion.

\section{SMALL STONES AND MEGALITHIC MONUMENTS}

If two broad characteristics can be discerned in accounts of the varied and often complex megalithic settings that were constructed during the later third and second millennia BC - stone rows, circles, cairns, standing stones and the like - the first is that these constructions invariably wove a range of differently sized stones into their fabric - from gravel up to often substantial megaliths. Second, whilst the larger slabs and megaliths have featured centrally in descriptive and interpretative accounts, the smaller of the stones have invariably been relegated to a supportive and frequently generalized role. This assigns them purely technological roles such as paving, cobbling or cairn material, unless they are of particularly unusual provenance, carry prior biographical traces (carving or reuse), have unusual material properties such as quartz, or some combination of the above. The latter tendency has been highlighted by Cooney $(2010,64-5)$ in the context of Neolithic studies more generally, who has drawn attention to an implicit contrast between stones he labels 'mundane' or 'routine' and those that are more visibly animated in academic discourse. Mundane stone is lithic material that is clearly bound up within the overall structural assemblage, yet whose presence it is safe to generalize into a neutral material background devoid of separate, or individual, meaning. In the context of monuments, this refers to stone that is invariably unworked, ubiquitous, small and/or deployed in roles traditionally regarded as a means-to-a-functional-end such as packing or the stones that together constitute a 
JOBNAME: No Job Name PAGE: 5 SESS: 11 OUTPUT: Fri May 29 17:57:38 2015 SUM: 1AE13436

/Xpp84_Wiley/wiley_journal_N-O/OJOA/ojoa_v34_i3/1ojoa_12056

MARK GILLINGS
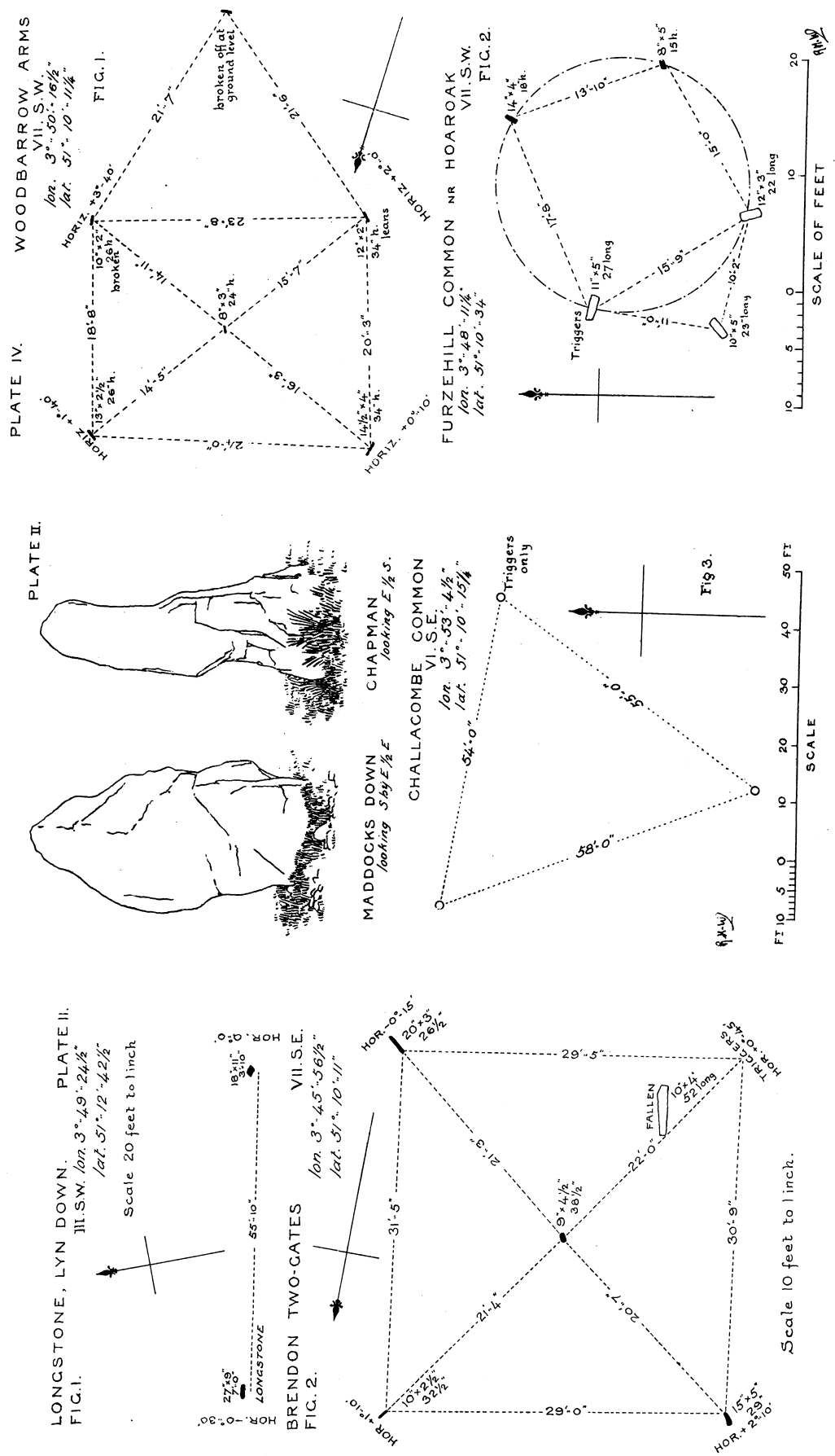

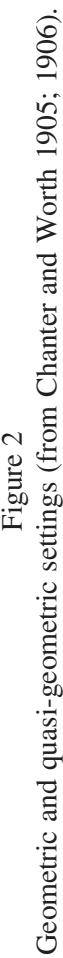



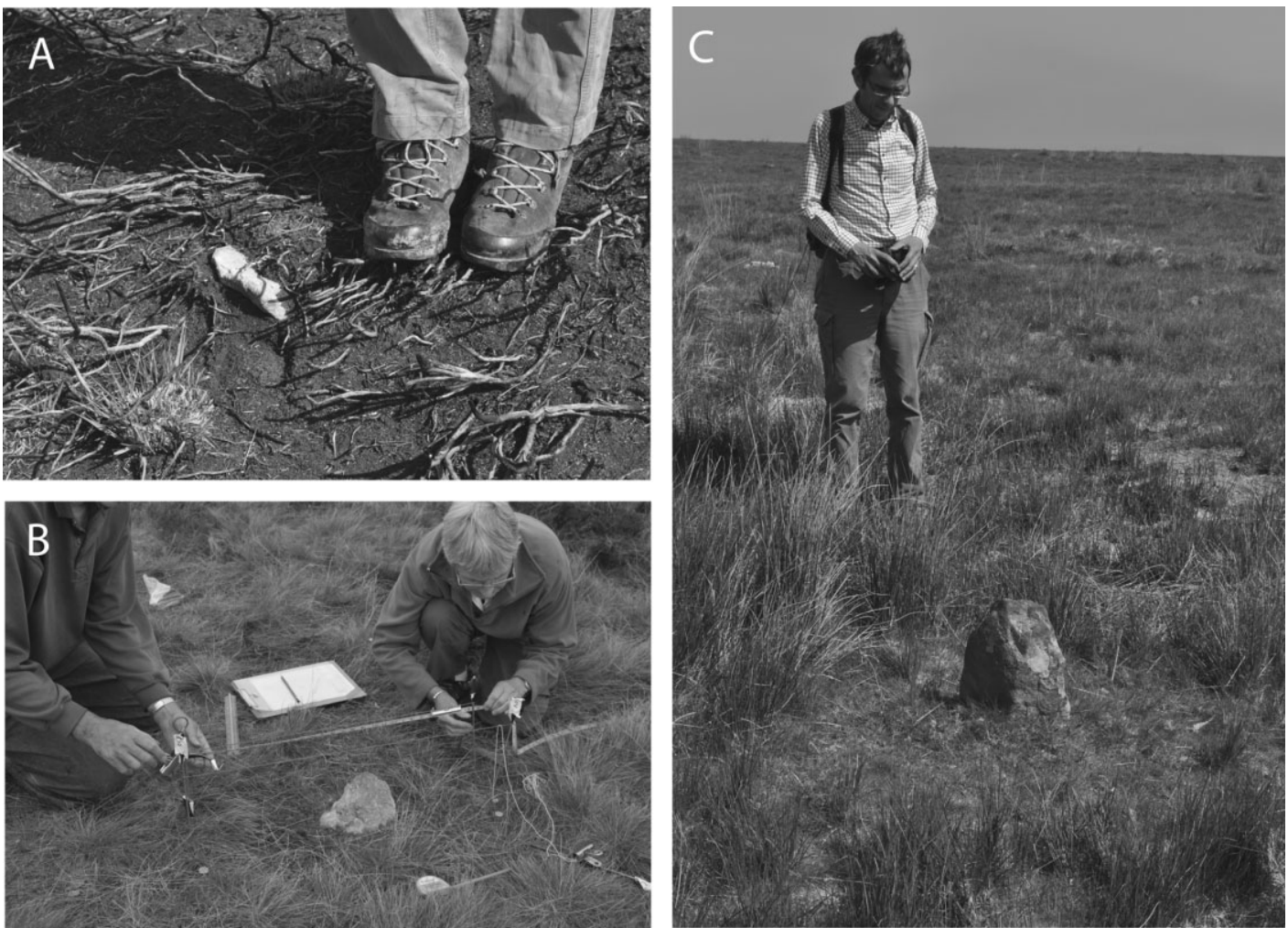

Figure 3

Minilithic settings on Exmoor (A - Porlock stone row; B - Porlock Circle (c) Barry Hitchcox; C - Lanacombe I), by author unless otherwise stated.

cairn. Cooney's basic argument, and it is a persuasive one, is that in eliding such material engagements from our narratives we may be unnecessarily restricting and limiting interpretational possibilities (ibid., 67-70).

Perhaps the most obvious way in which small stones are effectively excluded from discussion is through recording, and the imposition of an implicit size threshold above which individual stones are deemed significant and below which they are subsumed into a greater whole. Even in those rare cases where researchers have explicitly set out to consider all stones in a megalithic monument, thresholds are evident (e.g. Clare's decision to exclude stones that 'barely protrude above the grass' from his study on megalith size $(2010,246))$. The latter forms of anonymity can be purely descriptive, such as 'stone row' or 'circle', a measured average (such as typical stone height - e.g. Johnson and Rose 1994, 33, table 6) or both. Perhaps more subtle is the tendency to assume very small megaliths were broken-off 'stumps', with the implication that they were once much more substantial (e.g. Grinsell 1970, 39). Take, for example, descriptions of the partly excavated stone row at Leskernick, Bodmin. The excavators describe the monument thus: 'The stone row is just over 300m in length, oriented ENE-WSW and terminates at a "U"-shaped formation of three substantial, part turf-covered, recumbent stones just short of the cairn. The rest of the row consists of 47 small, low, and square-topped stones, 


\section{MARK GILLINGS}

mostly less than knee height' (Bender et al. 1997, 155). This is echoed in the English Heritage Pastscape record for the site: 'The majority of the stones, which include some fairly large boulders, protrude just above the ground surface level, however, one upright slab is $0.6 \mathrm{~m}$ high and a second $0.4 \mathrm{~m}$ high' (English Heritage 2007).

I would argue that small standing stones - miniliths - are routinely relegated to Cooney's mundane background, escaping detailed record and being subsumed into the larger monumental whole. This academic partitioning is curious. It does not seem to be a tacit reflection of the degree of input that is thought to have gone into the fashioning of a given artificial setting; as the examples will demonstrate, even very small stones can be carefully chosen and deliberately set and supported in quite elaborate stoneholes. Nor does it seem to reflect a straightforward functional attempt to distinguish between distinctive 'ends' and the means to achieve those ends (i.e. the role of packing stones to enable uprights to remain upright). Whatever the reasons behind this academic blind-spot, the argument here is that it is ripe for reappraisal.

\section{HOW UNUSUAL ARE MINILITHS?}

Although claims for Exmoor's megalithic uniqueness have been articulated around its tiny stones, the presence of very small standing stones is far from unusual, particularly in the case of certain types of monument such as stone rows and circles (see Herring 2008; examples in Burl 1976; 1993). What is more unusual is monuments such as the Exmoor geometric settings, which are fashioned either entirely from very small upright stones or structures where small uprights dominate, often in complex combinations and associations with more imposing megaliths (see below). At this point it is worth confronting a fundamental question that is not only relevant to the selection of sites reviewed, but also key to any discussion reviewing the interpretative status afforded to very small stones: how diminutive does a given standing stone have to be, to be considered sufficiently small (or minilithic)? The answer is not straightforward. Any threshold is inevitably arbitrary and as a result open to challenge; it further runs the risk of channelling debate into a deadening classificatory cul-de-sac from which it may never return. In addition, the tendency for researchers to record only the largest stones (presumably deemed most significant) in any given circumstance makes the determination of a cut-off or threshold difficult. Further, the decision as to what constitutes 'small' appears to be very much context dependent. For example, ranging in height between 0.97 and $1.6 \mathrm{~m}$, the inner settings of Avebury's southern inner circle described by Smith as of 'small size' are certainly diminutive in comparison with the stones around them (not least the $6.4 \mathrm{~m}$ long obelisk), yet would tower over the bulk of uprights discussed below (Smith 1965, 199). This perhaps explains the wisdom of researchers such as Emmett, who whilst willing to identify a range from what he terms 'small stones' $(0.1 \mathrm{~m})$ to 'those of megalithic proportions' $(2.5 \mathrm{~m})$ elects not to identify precisely where along this continuum the status of a given stone changes (Emmett 1979, 96, appendix A). The approach taken here in selecting sites for discussion has been entirely pragmatic, shaped by the direct experience of excavating megaliths that sit at either end of Emmett's scale (Gillings et al. 2008; 2010). The unstated rule-of-thumb has been whether a given stone could have been moved easily by, at most, two people working in tandem - an example of the kind of 'small act' discussed by Smyth (cited in Cooney 2010, 69-70). Whilst this criterion has been useful for the study carried out here, I am confident that other, more rigorous metrical criteria could be applied if desired. 
JOBNAME: No Job Name PAGE: 8 SESS: 11 OUTPUT: Fri May 29 17:57:38 2015 SUM: 6518BB6C

/Xpp84_Wiley/wiley_journal_N-O/OJOA/ojoa_v34_i3/1ojoa_12056

BETYLMANIA? - SMALL STANDING STONES AND THE MEGALITHS OF SOUTH-WEST BRITAIN

Perhaps more important than the application of a rigid set of criteria is that researchers be encouraged to pause before the application of any cut-off, however commonsensical it might at first seem.

\section{MINILITHIC MONUMENTS}

In the case of the Copney Stone Circles, County Tyrone, peat clearance revealed a complex of over 100 stone circles taking a variety of forms yet sharing a similar preference for small upright stones (0.1-0.5 $\mathrm{m}$ in height) (Fig. 4). Associated with a number of the circles are alignments of paired stones - one large and one small, extending up to $50 \mathrm{~m}$ from the circles themselves (Foley and MacDonagh 1998, 24). Three circles were cleared of peat but not subjected to any further excavation. Fully exposed, Circle A was $16 \mathrm{~m}$ in diameter, its perimeter defined by 130 close-spaced stones enclosing over 300 small uprights (typically $0.2 \mathrm{~m}$ high) radiating in lines from a central cairn (ibid., 27). The perimeter of Circle B (18 $\mathrm{m}$ in diameter) enclosed over 500 standing stones (typically $0.3 \mathrm{~m}$ in height) in a series of concentric circles. This concentric pattern was mirrored in Circle $\mathrm{C}$, the largest investigated ( $24 \mathrm{~m}$ in diameter), although only a quadrant of the latter was cleared of peat. Extending from Circle B was a parallel alignment of paired large $(0.4-0.8 \mathrm{~m})$ and small $(0.13-0.32 \mathrm{~m})$ uprights.

Some $11 \mathrm{~km}$ to the north-east of Copney, the Beaghmore complex comprises seven irregular stone circles along with eight stone alignments and 15 cairns. Excavations carried out between 1945-9 revealed 1269 standing stones sealed beneath the peat (Fig. 5). As at Copney, there is evidence of deliberate pairing between large and small stones - take, for example, the paired alignments L6 (of stones $0.94 \mathrm{~m}$ in height) and L5 (described merely as consisting of 'numerous small stones') (May and Mitchell 1953, 179). Of most interest is Circle E, whose interior was 'evenly studded with 884 small stones' (ibid., 184) that Thom later recorded as standing to a typical height of $0.38 \mathrm{~m}$ (Thom 1980, 16). As for patterning within this spread, the excavator noted the presence of both curves and lines. These are certainly evident on the published plan (reproduced in part in Fig. 5), but the degree to which the latter was measured (as opposed to impressionistic) is unclear (May and Mitchell 1953, 185). Although the site was subsequently surveyed by Thom as part of an astronomical investigation, the small stones were (rather tellingly) excluded from his published plan, Circle E being represented as a simple ring. Aligned at a tangent to the perimeter of Circle $\mathrm{E}$ is a paired large-small alignment (L7 and L8; May and Mitchell 1953, pl. XXXV), the stones making up L7 the largest on the site (see Fig. 5).

At neither site do we have information regarding the way in which the small megaliths were erected and fixed in place; in both cases the emphasis was on revealing the plan. As a result, we have no idea whether the practices used to raise the large/small stones comprising the paired alignments were shared or different, or, for example, how the 884 stones filling Beaghmore Circle E were set in place. The same could not be said of the well-excavated site of Stackpole Warren in Pembrokeshire, where a similar play between megaliths large and small is in evidence. Partly overlying the site of an earlier Bronze Age roundhouse, a setting of over 2000 small upright stones was associated with a large standing stone (the Devil's Quoit, a limestone slab $2.4 \mathrm{~m}$ in maximum dimension) and a short alignment of water-worn stones (Fig. 6). Dating to the later Bronze Age, the stone setting covered a trapezoidal area of $16 \times 8 \mathrm{~m}$ with a stone-free zone along the centre. That this was not a haphazard or ad hoc collection is suggested by the uniform shape of the individual stones and their configuration. The component miniliths were in the main of limestone and elongated in shape, $0.1-0.3 \mathrm{~m}$ in length (with the bulk falling within the range 


\section{MARK GILLINGS}

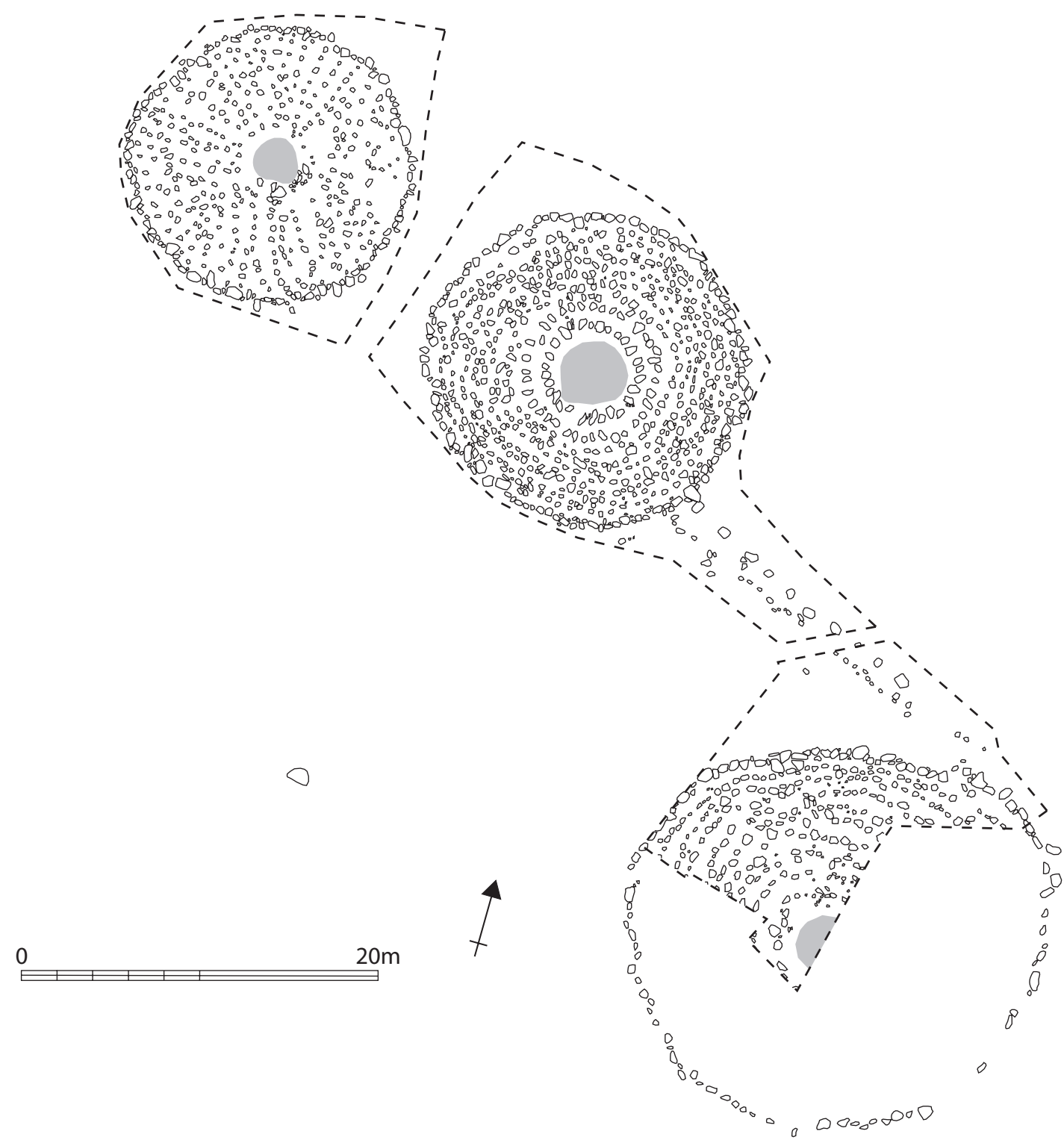

Figure 4

The Copney Circles (after Foley and MacDonagh 1998).

$0.18-0.25 \mathrm{~m})$. The majority were wedge-shaped, with the point forming the base, and all were originally thought to have been set upright in a series of irregular rows running parallel to the long axis of the spread (Benson et al. 1990, 190). The suggestion is of careful selection, movement and placement; over 2000 discrete and meaningful material acts. Precise phasing is uncertain but, as noted, a substantial standing stone was erected on the axis of the setting at the south-west end (ibid., 194, fig. 15) along with a $4 \mathrm{~m}$ alignment of five upright, rounded boulders 
JOBNAME: No Job Name PAGE: 10 SESS: 11 OUTPUT: Fri May 29 17:57:38 2015 SUM: 1D5AC83D

/Xpp84_Wiley/wiley_journal_N-O/OJOA/ojoa_v34_i3/1ojoa_12056

BETYLMANIA? - SMALL STANDING STONES AND THE MEGALITHS OF SOUTH-WEST BRITAIN

Schematic Representation of Beaghmore Monuments

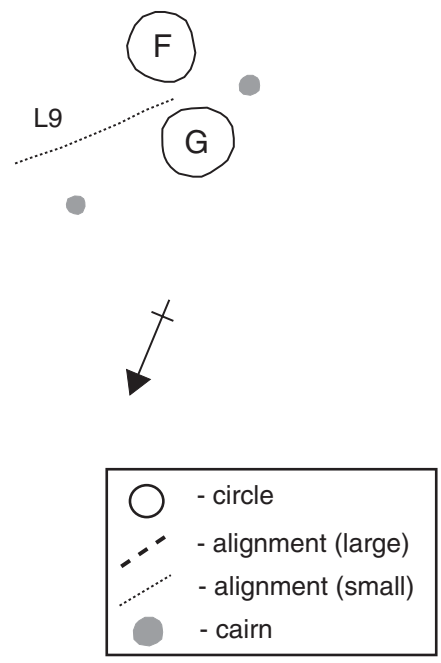

0
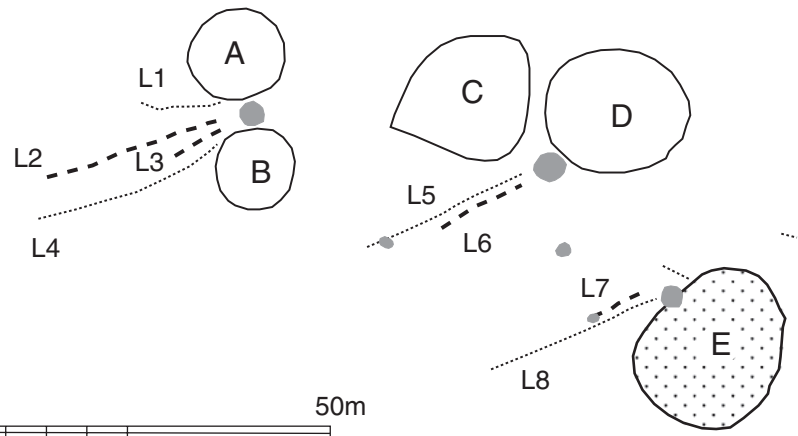

$50 m$

Circle E

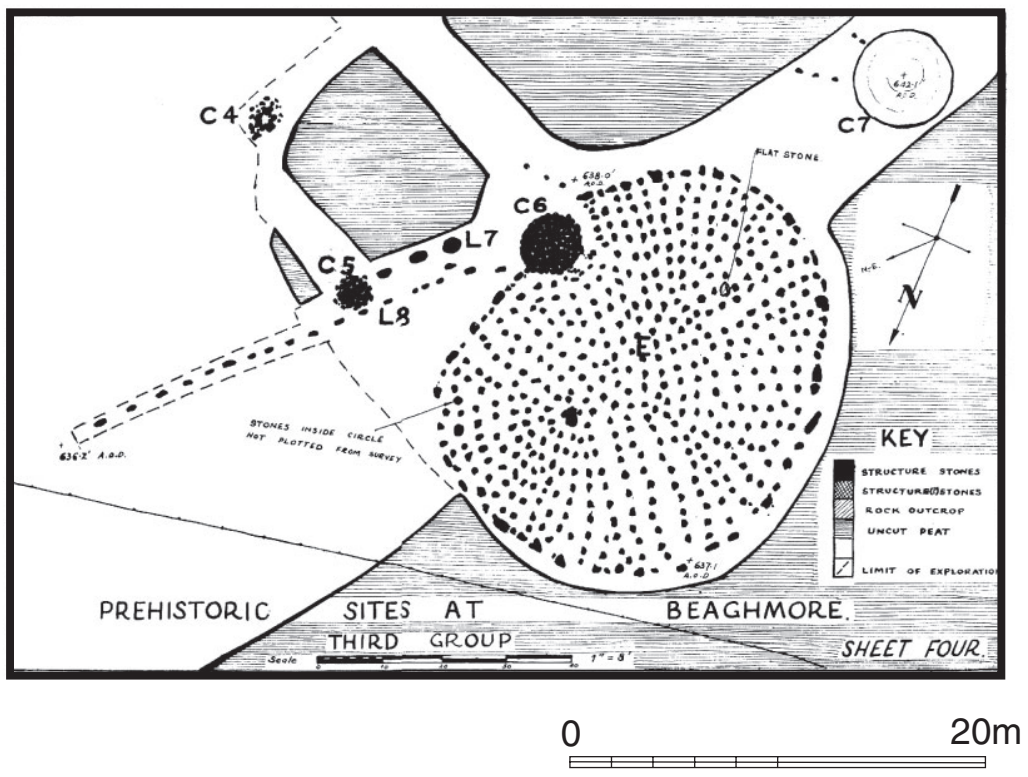

Figure 5

The Beaghmore monuments (after May and Mitchell 1953; Burl 1976). 
JOBNAME: No Job Name PAGE: 11 SESS: 11 OUTPUT: Fri May 29 17:57:38 2015 SUM: 1B95EDF9

/Xpp84_Wiley/wiley_journal_N-O/OJOA/ojoa_v34_i3/1ojoa_12056

\section{MARK GILLINGS}
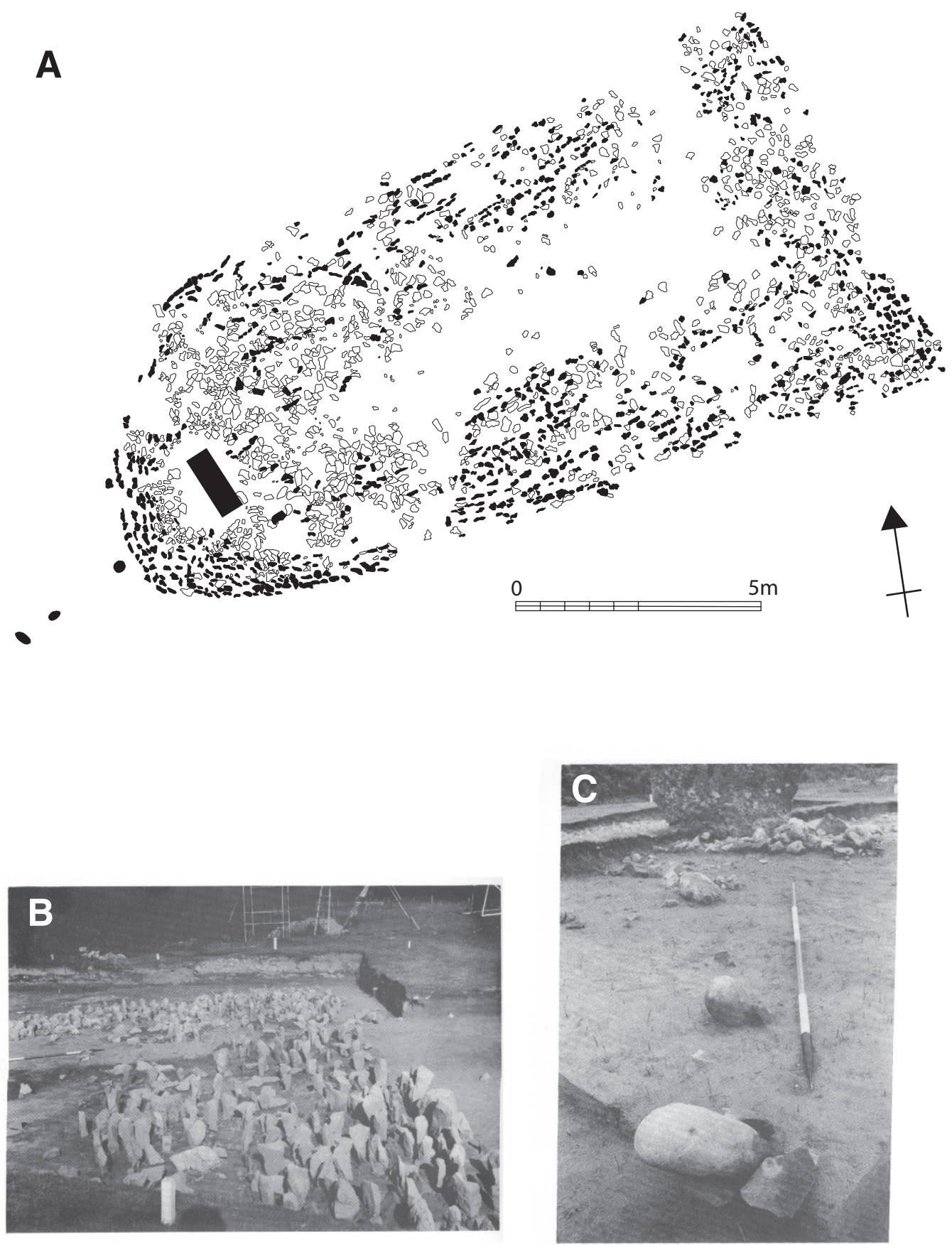

Figure 6

Stackpole Warren (A - plan of stone settings (after Benson et al. 1990); B - the stones of the setting; C - the line of rounded boulders (from Benson et al. 1990)). 
(c.0.2-0.3 $\mathrm{m}$ in maximum dimension) that served to continue the axial alignment to the southwest (ibid.; Williams 1988, 99). Unfortunately, whilst there is extensive discussion of the technology and stages involved in raising the $2.4 \mathrm{~m}$ long megalith, the small elongated stones are described simply as being 'set'. No detail is given as to how exactly this was effected - the published sections give no indication of any cuts or sockets associated with the stones so the assumption must be that they were pushed sharp end first into the ground surface; the same applies to the alignment of rounded stones (Benson et al. 1990, fig. 8).

Where careful record has been made of the technologies used to raise small standing stones, the results have been unexpected. For example, recent fieldwork on the multiple stone rows of Battle Moss, one of a group of such sites in Caithness, has provided useful detail on the practices that attended the raising and fixing into place of small megaliths (Fig. 7). The site originally comprised eight approximately parallel rows of $c .160$ stones - typically $0.3 \mathrm{~m}$ in height - stretching for a distance of $c .40 \mathrm{~m}$, with the easternmost row extending for a further $77 \mathrm{~m}$ or so (Canmore record no. 9021; Caithness Archaeological Trust 2004). Excavation carried out in 2003 on an area encompassing seven stones revealed that each had been placed in a deliberately dug narrow slot lined with clay and/or turf, the stone being held in place by packing stones pushed in at each side. A layer of what was interpreted as redeposited natural was then used to create a low platform around each upright stone (Baines et al. 2003, 95), practices more in common with conventional megalithic settings.

The observed pattern of a conventional megalith set at one end of a smaller stone setting seen at Stackpole Warren was echoed, albeit on a less impressive scale, at the sites of Miskin and Mynydd Llangyndeyrn 17 in south Wales (Fig. 8). At the former, a 'boat-shaped' spread of small, irregular stones extended $1.45 \mathrm{~m}$ from the edge of a $1.2 \mathrm{~m}$ high pennant sandstone upright, described variously by the excavator as capping or paving (Vyner 1977, 19). In the stonehole of the standing stone was a substantial slab of the same sandstone laid hard against the northern edge along with a whetstone and a small number of rounded pebbles. The former was argued to have been broken from the top of the megalith prior to erection; none of the stones found in the stonehole functioned as packing (ibid., 22; Williams 1988, 80-1). At Mynydd Llangyndeyrn 17, a similar low, flat spread of irregular stones extended $1.6 \mathrm{~m}$ to the east of a $1 \mathrm{~m}$ high megalith, both located within a cleared area in a natural stone spread (Ward 1983, 42-3). Once again the stonehole fills were unusual; in this case smaller stones were wedged between the ends of the long axis of the stone and the stonehole cut, effectively bisecting the stonehole. Distinctive soils were then used to fill the two sides. Assigning the spread of stones a symbolic role, the excavator drew attention to the apparent play between large and small stones evident at the site, suggesting a deliberate referencing of the broader chambered tomb tradition of combining orthostats with accumulations of small stone (ibid., 46).

One of the most subtle, yet striking instances of this complex interplay between megalith and minilith was encountered at the moorland site of Rhos-y-Clegyrn in Pembrokeshire, where an oval spread of what was described as cobbling extended to the north of a $2.74 \mathrm{~m}$ high standing stone of local igneous rock (Fig. 9). Needless to say, no details are given as to the stones making up this spread, but directly adjacent to the stone on the east side and cutting the edge of the stonehole was a small pit filled with a clean blue-white clay that contained two further upright stones, described as pillar-shaped. The first was of sandstone and stood $0.30 \mathrm{~m}$ above the base of the pit, sitting directly upon two sherds of pottery; the second (geology not specified) was only $0.11 \mathrm{~m}$ in height and gains only the barest mention in the published report. The first of these is likely to have just poked above the ground surface. A further 
JOBNAME: No Job Name PAGE: 13 SESS: 11 OUTPUT: Fri May 29 17:57:38 2015 SUM: 242F4629

/Xpp84_Wiley/wiley_journal_N-O/OJOA/ojoa_v34_i3/1ojoa_12056

\section{MARK GILLINGS}

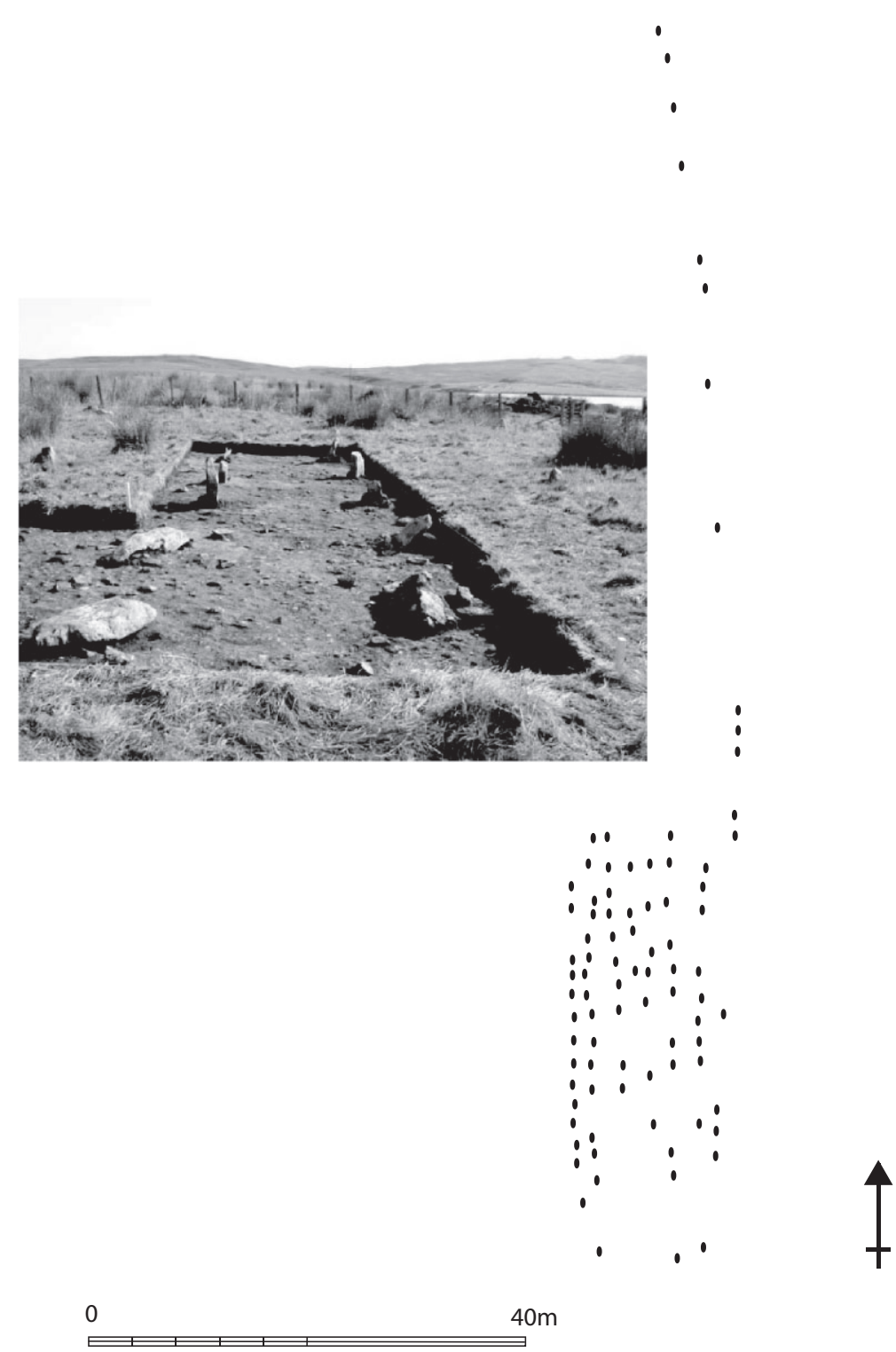

Figure 7

2 Plan of Battle Moss stone rows and 2003 excavation (after Dryden, H. and Shearer, R.T. 1871, Battle Moss, Loch of Yarrows, plan of stones with measurements and annotations (Canmore item SC604350) and Baines et al. 2003, fig. 46).

eight features likewise interpreted as small pits were excavated within the area of the stone spread and on its perimeter, some of which also displayed evidence of having held one or more small uprights (of stone in the case of C and wood/stone D, L, M). Other features within the oval defined by the stone spread took the form of stone rings (0.9-1.4 m diameter) composed of small 
A

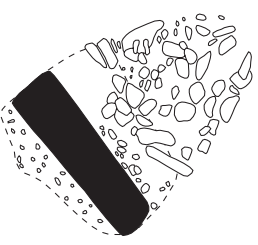

B

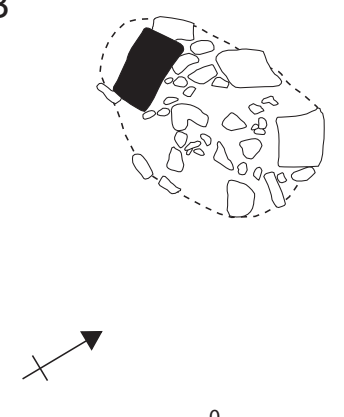

0

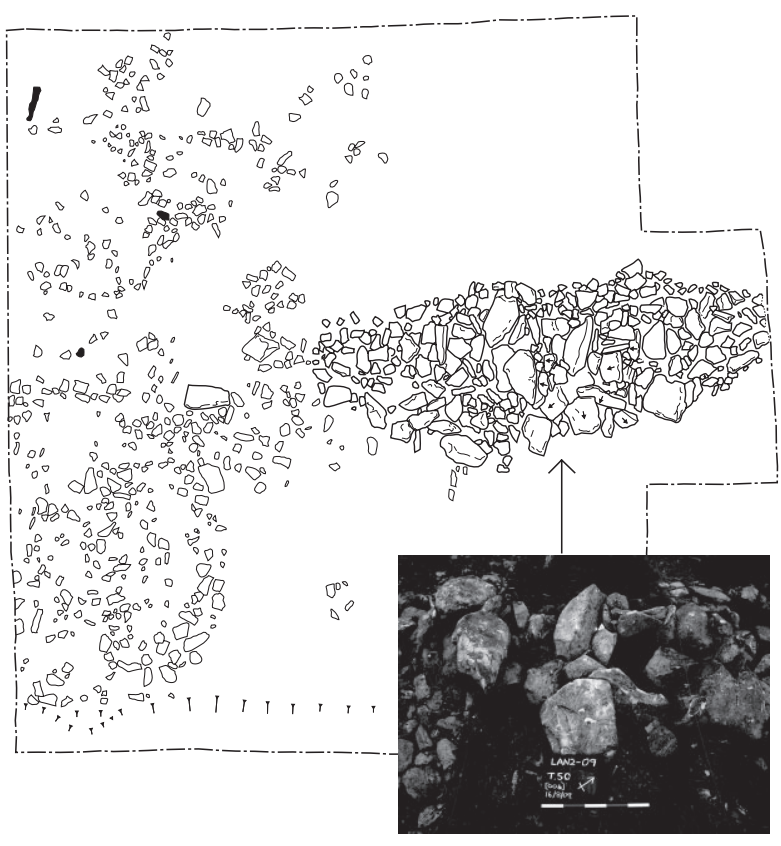

$5 m$

ydd Llangyndeyrn 17; C - Lanacombe II (after Williams 1988;

The 'boat-shaped' spreads (A - Miskin; B - Mynydd Llangyndeyrn
Gillings 2013).

uprights, placed pebbles and coursed stone. The site clearly had a long and complex biography, with the oval spread seemingly the latest feature (Lewis 1966, 256-9; 1975, 19-27).

\section{BACK TO THE STONE SETTINGS OF EXMOOR}

Far from being incidental to the main structures, small uprights were being deployed in a deliberate and often sophisticated fashion; despite this, with the exception of Battle Moss, their recording has been at best superficial. The result has been a tendency to focus interpretation at the scale of the overall site plan. Take, for example, Stackpole Warren, where it was assumed by the excavators that the 2000 small stones of the main setting were originally upright. This is despite the fact that the surviving upright and leaning stones lay in parallel lines, which seems fortuitous in the extreme. An alternate reading would suggest deliberate placement (or selective lowering) of upright and recumbent miniliths to stress this linearity. However, we have no record of how the uprights were set, whether this was consistent, or whether the flat stones were accompanied by empty stoneholes. This is where recent work on Exmoor may help. Since 2007, a series of small-scale excavations have taken place on individual miniliths as part of the National Parks' ongoing monument management initiatives. Targeting stones that had suffered recent displacement or toppling, a total of six miniliths have been investigated at three settings, including three of the 13 stones that together make up the setting of Lanacombe I (Figs. 10 and 
JOBNAME: No Job Name PAGE: 15 SESS: 11 OUTPUT: Fri May 29 17:57:38 2015 SUM: $193 B 8182$

/Xpp84_Wiley/wiley_journal_N-O/OJOA/ojoa_v34_i3/1ojoa_12056

\section{MARK GILLINGS}
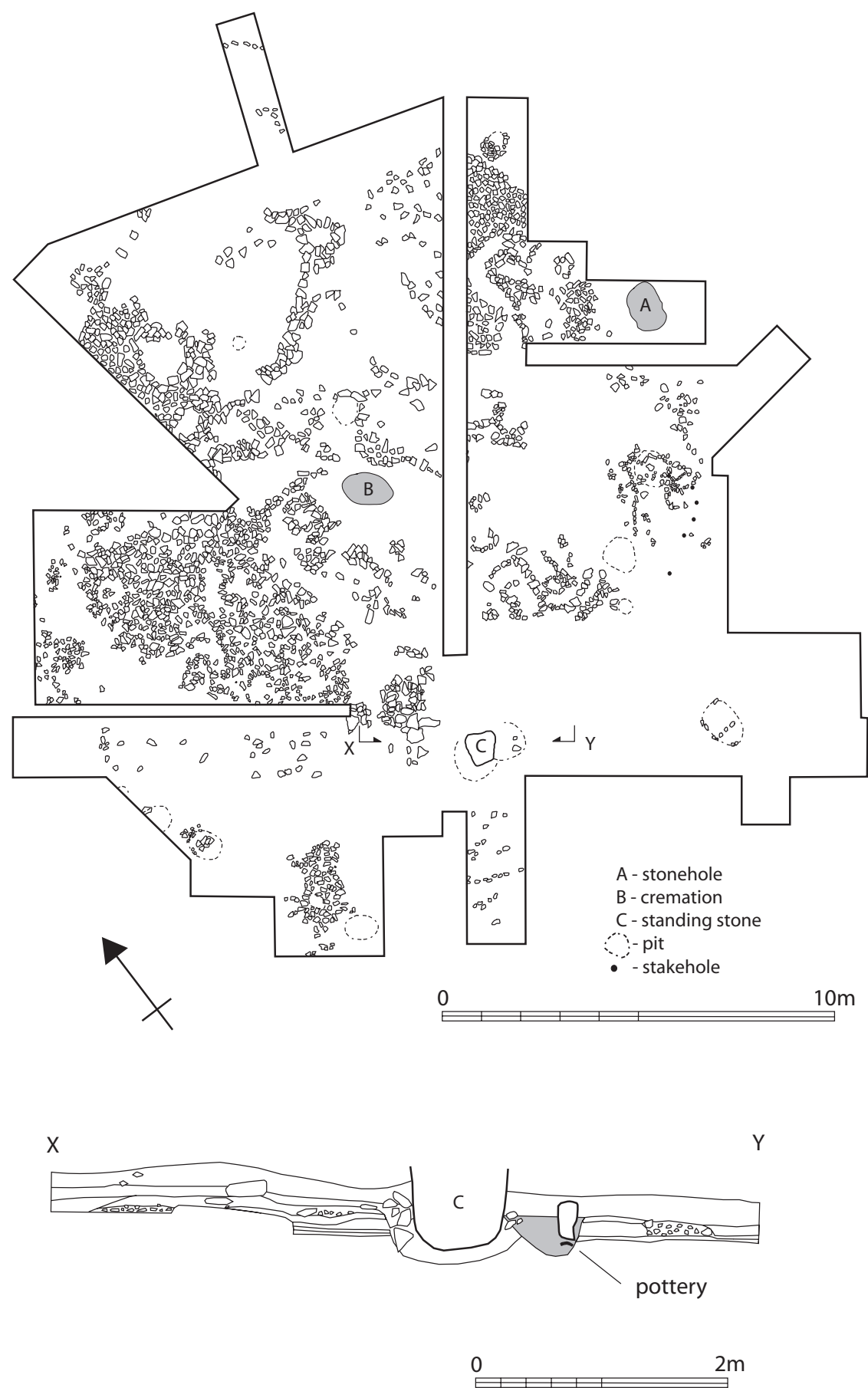

Figure 9

Rhos-y-Clegyrn Period II (after Lewis 1966, fig. 2; 1975, fig. 3). 

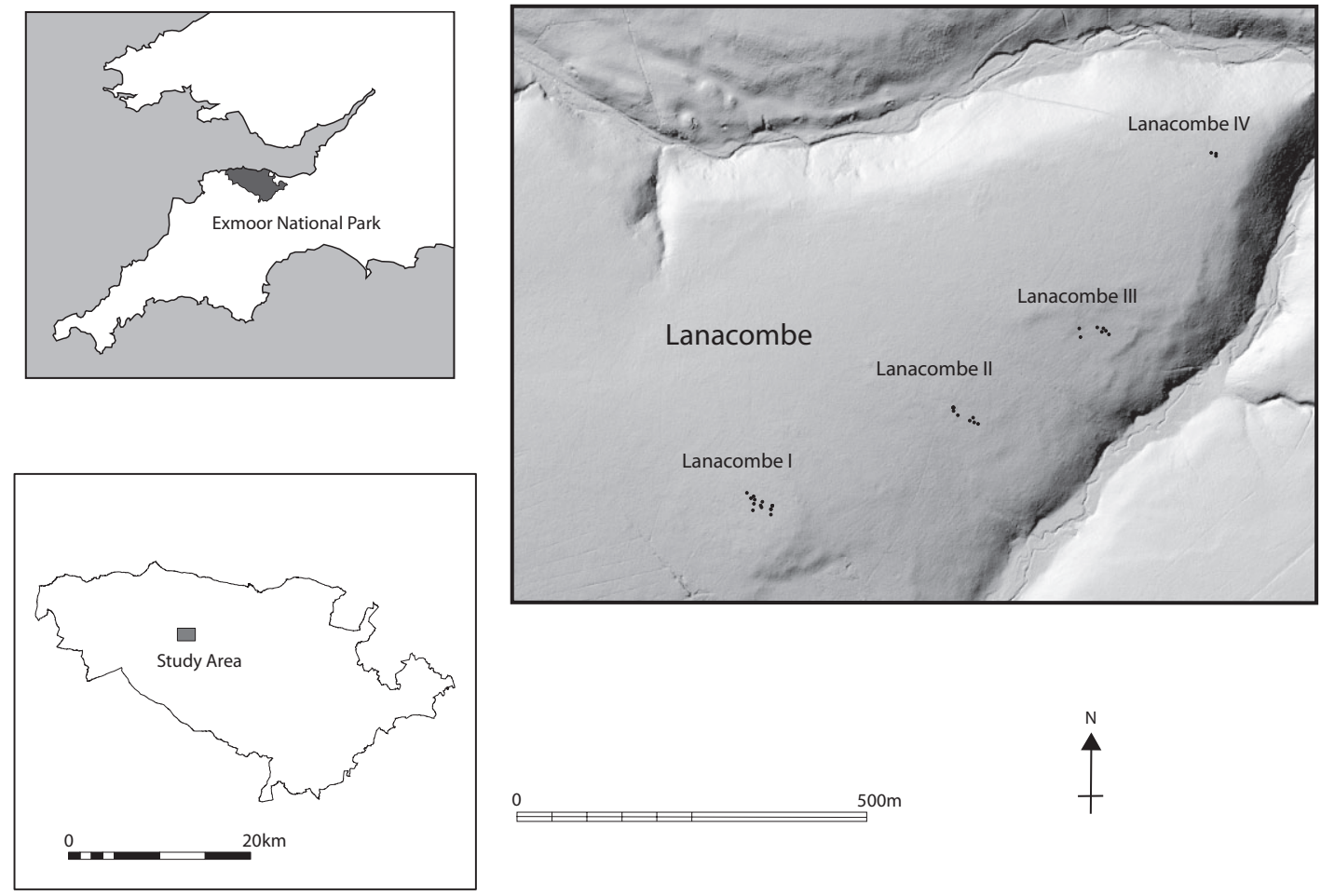

Figure 10

Location plan of the Lanacombe settings.

11). This programme of stone investigation culminated in the excavation in 2013 of a portion of the perimeter of Porlock Stone Circle encompassing three stone positions. As well as focused work on the stones, programmes of geophysical survey and excavation in the wider landscape have also been carried out to contextualize better the settings (e.g. Gillings 2013). As the detailed results of this work have been fully published, only a summary of the key findings is included below. In all cases the stones discussed are of local sandstone.

\section{Lanacombe I}

Standing to an original height of $c .0 .54 \mathrm{~m}$, stone $\mathrm{H}$ of Lanacombe 1 was a subrectangular slab placed at one end of a carefully dug stonehole, hard against an area of outcropping natural (Fig. 12). Small flat stones had been placed on the base of the stonehole to create a level surface and had been pressed against the upright stone as part of a primary fill of clean brown soil. Pushed into this soil and in direct contact with one end of the standing stone was a single tabular piece of struck quartz. The stonehole was then levelled with a gravelly layer of weathered sandstone. Neither of these distinctive fills appears to have originated from the digging out of the original stonehole and had to have been brought to the location for this express purpose. Aligned on the upright stone and disappearing into the section to the south-west was a 
JOBNAME: No Job Name PAGE: 17 SESS: 11 OUTPUT: Fri May 29 17:57:38 2015 SUM: 2BECFEAF /Xpp84_Wiley/wiley_journal_N-O/OJOA/ojoa_v34_i3/1ojoa_12056

\section{MARK GILLINGS}

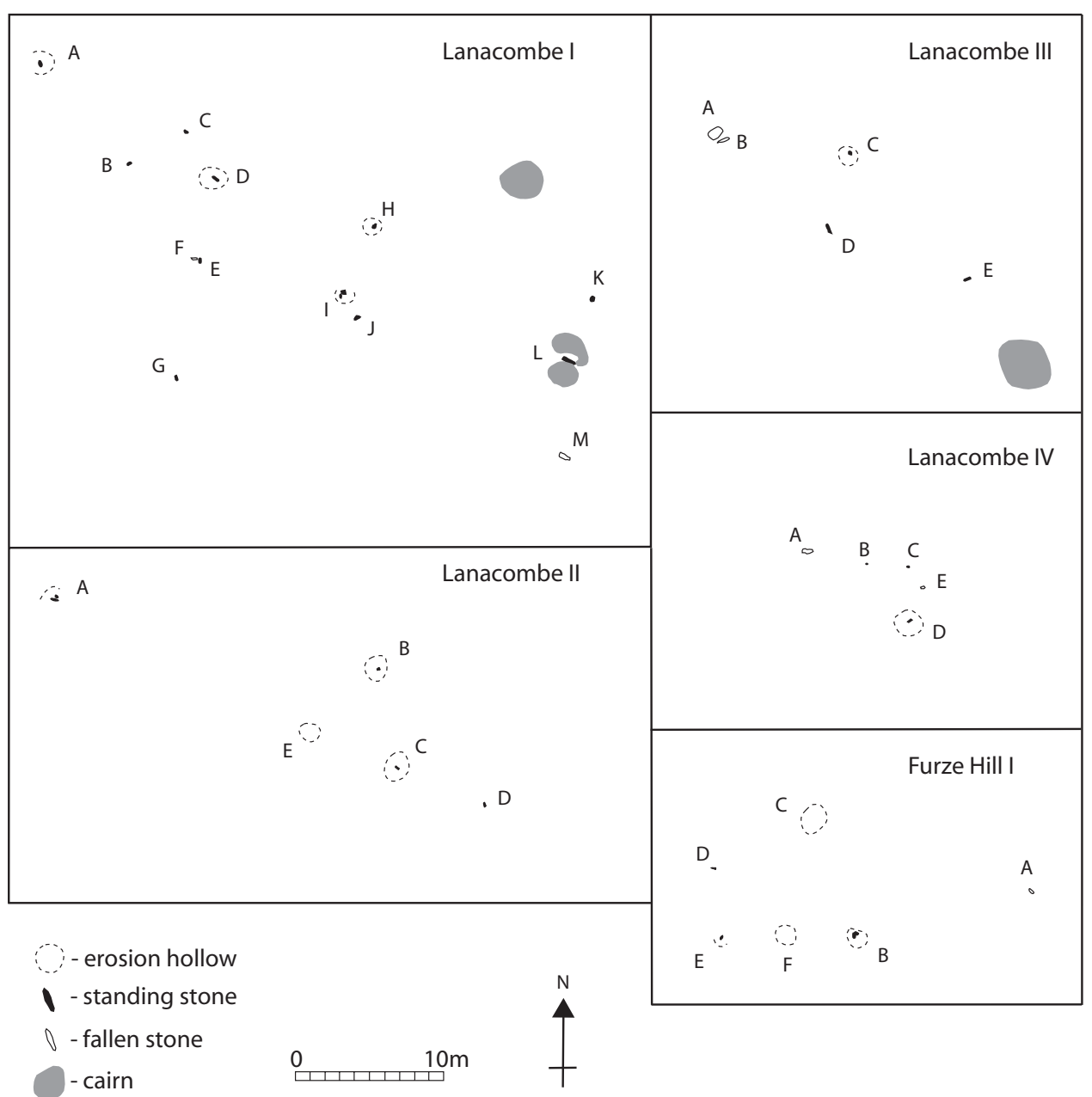

Figure 11

Plans of the settings discussed in the text (after Quinnell and Dunn 1992).

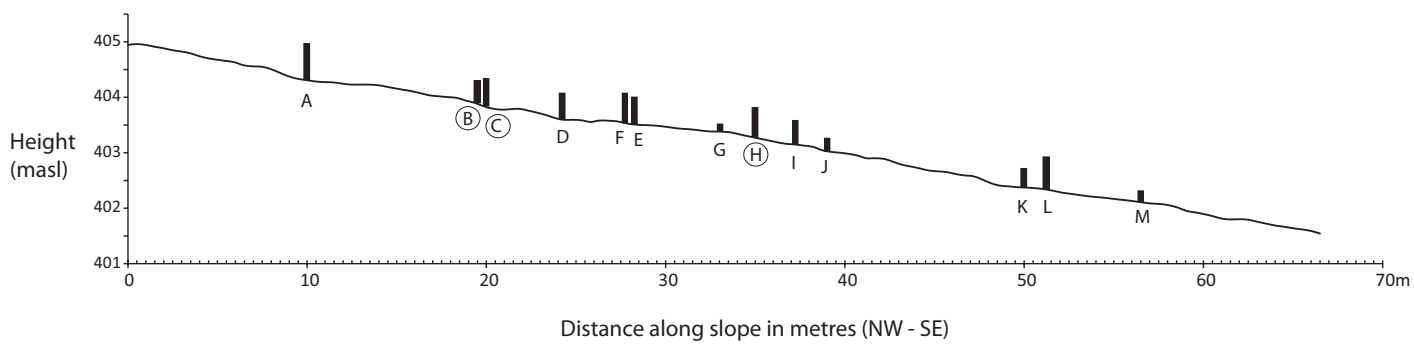

Figure 12

Schematic profile of Lanacombe I showing relative heights of uprights. 
line of four larger pieces of flat sandstone (Gillings et al. 2010, 309-11). Originally standing to a height of $c .0 .46 \mathrm{~m}$, stone $\mathrm{C}$ was slotted into a carefully constructed box or cist of small orthostats (maximum dimension $0.2 \mathrm{~m}$ ) that had been set within a shallow hollow in the underlying natural and packed into place with a deposit of silty clay. Like a tailor-made slot for a rather irregular peg, the shape of the box carefully mirrored that of the base of the stone, serving to fix it firmly in place (Gillings and Taylor 2011a, 27-9). The final stone investigated, stone B (standing $0.32 \mathrm{~m}$ high), lacked any formal stonehole, being packed into place by a low cairn of poorly sorted, sub-angular pieces of sandstone (0.05-0.2 $\mathrm{m}$ in maximum dimension). Although disturbed by recent damage, there are suggestions from the published plan that this too was structured around a deliberately constructed box, this time erected within the body of a low cairn. As with stone $\mathrm{H}$, a tabular piece of quartz had been placed at one end of the stone (ibid., 25-7).

\section{Lanacombe II}

Although no standing stones were investigated, excavations carried out $20 \mathrm{~m}$ to the south-west of the setting revealed a pair of small, aligned cairns, linked on their shared long axis by a $7 \mathrm{~m}$ long arrangement of large, widely spaced stones. In its final phase the westernmost was circular, with a rectangular cist of orthostats at its core. Of most interest is the eastern. Retaining a distinctive boat shape, the core of this low cairn comprised a very irregular box of orthostats against which flat slabs of sandstone had been laid, onion-skin fashion (Gillings 2013, 44-7) (Fig. 8). Although not considered in the final report, this box could be interpreted as less a structural consequence of the onion-skin technique used to build the cairn and instead the support for a now removed standing stone; a box of the kind seen at Lanacombe I stones B and C, only of an order of magnitude larger. If so, then we have a group of features close to the main cluster of miniliths making up the Lanacombe II setting that echo elements discussed earlier at sites such as Stackpole Warren (the stone alignment), Miskin and Mynydd Llangyndeyrn 17 (the boatshaped stone spread and standing stone).

\section{Lanacombe III}

Stone $\mathrm{C}$ comprised a $0.86 \mathrm{~m}$ long stone, square in section and tapering to a sharp spike at the base. To fix it in place an oval slot had been dug and the stone rammed into it. It was then packed into place with the material originally dug from the hole along with a number of pieces of flat sandstone wedged against the sides of the upright to keep it in place (Gillings et al. 2010, 310-12).

\section{Lanacombe IV}

Stone $\mathrm{D}$ took the form of an elongated diamond standing to a height of c. $0.8 \mathrm{~m}$. An over-sized stonehole had been dug and the stone placed hard against one edge (Fig. 13B). It was then fixed into place with the soil that had been dug out, with no use of packing stones (Gillings and Taylor 2011a, 28-32).

\section{Furzehill Common I}

Located $4 \mathrm{~km}$ west-north-west of Lanacombe, the stone setting Furzehill Common I was first recorded in 1970 when it comprised four stones (two standing (stones E and B); two 


\section{MARK GILLINGS}
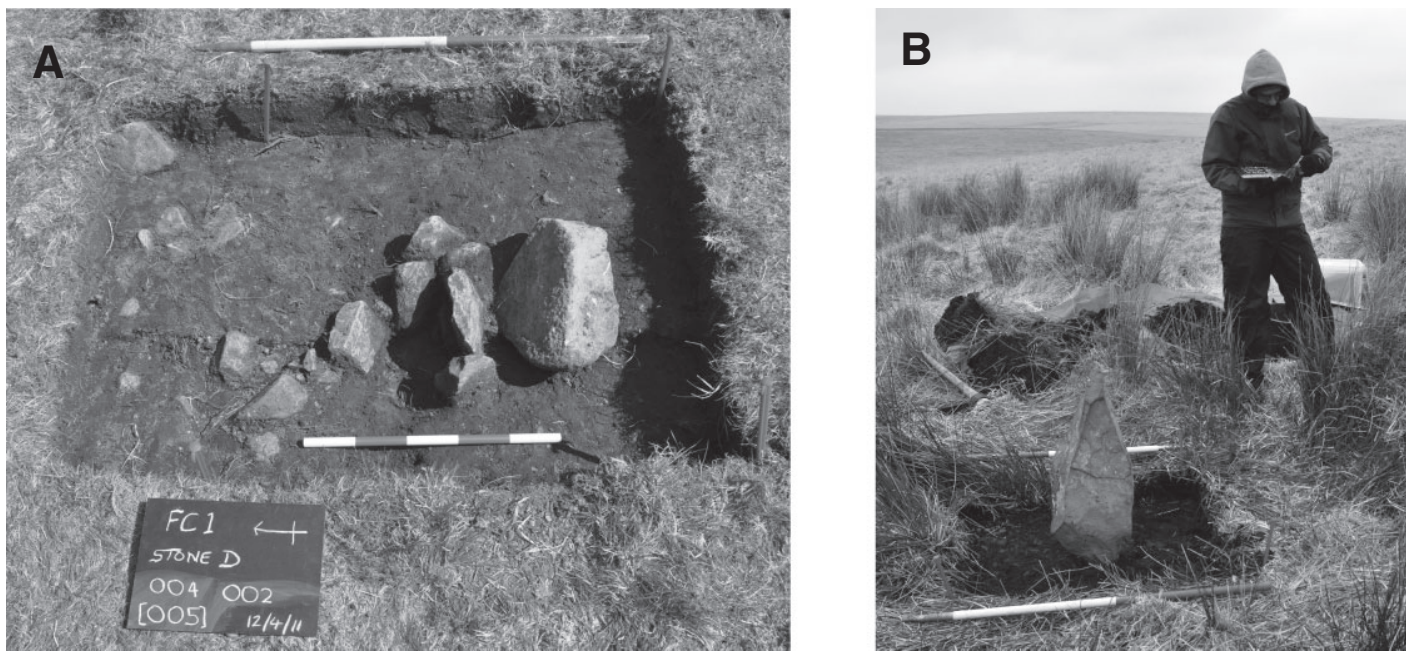

Figure 13

Furzehill Common (A) and Lanacombe IV (B), photographs by author.

recumbent (A and D)) and two erosion hollows (C and F) assumed to mark the positions of former uprights (Fig. 11). The status of stone D as a bona fide component of the setting was unclear, a piece of sandstone just protruding through the turf, one of many such stones noted but excluded from the formal survey (Quinnell and Dunn 1992, 24). Upon excavation, stone D proved originally to have been a $0.23 \mathrm{~m}$ high upright held in position by a ring of sandstone orthostats (maximum dimension $0.28 \mathrm{~m}$ ) that had been erected in a small oval stonehole, giving the feature a cist or box-like appearance akin to Lanacombe I stone C (Fig. 13A). Lying next to the stonehole and parallel with it was the minilith which appears to have been carefully extracted, with minimum damage or disturbance to the supporting box; indeed only recent displacement caused by bracken roots prevented the upright from slipping straight back in when consolidated (Gillings and Taylor 2011b, 3-5). Dating of this removal event is uncertain though there is the suggestion that it might be very early in the life of the upright. There was certainly nothing stratigraphically to separate the stonehole and stone.

\section{Porlock Circle}

Porlock Circle currently comprises 18 stones, ranging in height from 0.07 to $0.65 \mathrm{~m}$ (Fig. 14). Excavation carried out in 2013 on the northern arc of the circle identified three previously unrecorded stoneholes (Features 4, 5 and 6) as well as confirming that two currently standing stones were late twentieth-early twenty-first century additions (for detail, see Gillings forthcoming). Feature 6 comprised a large, oval stonehole $(0.60 \times 0.50 \mathrm{~m}$ and reaching a depth of $0.37 \mathrm{~m}$ ). Interestingly, the stonehole was sloping rather than vertical, the base tilting markedly to the east where the feature was undercut. The fill of the stonehole was dominated by a dense concentration of stone comprising 53 pieces of sandstone, which ranged in size from 0.04$0.16 \mathrm{~m}$ in maximum dimension (Fig. 15). The majority of these took the form of thin wedges that had either been specially selected or deliberately flaked. At the bottom of the stonehole were 


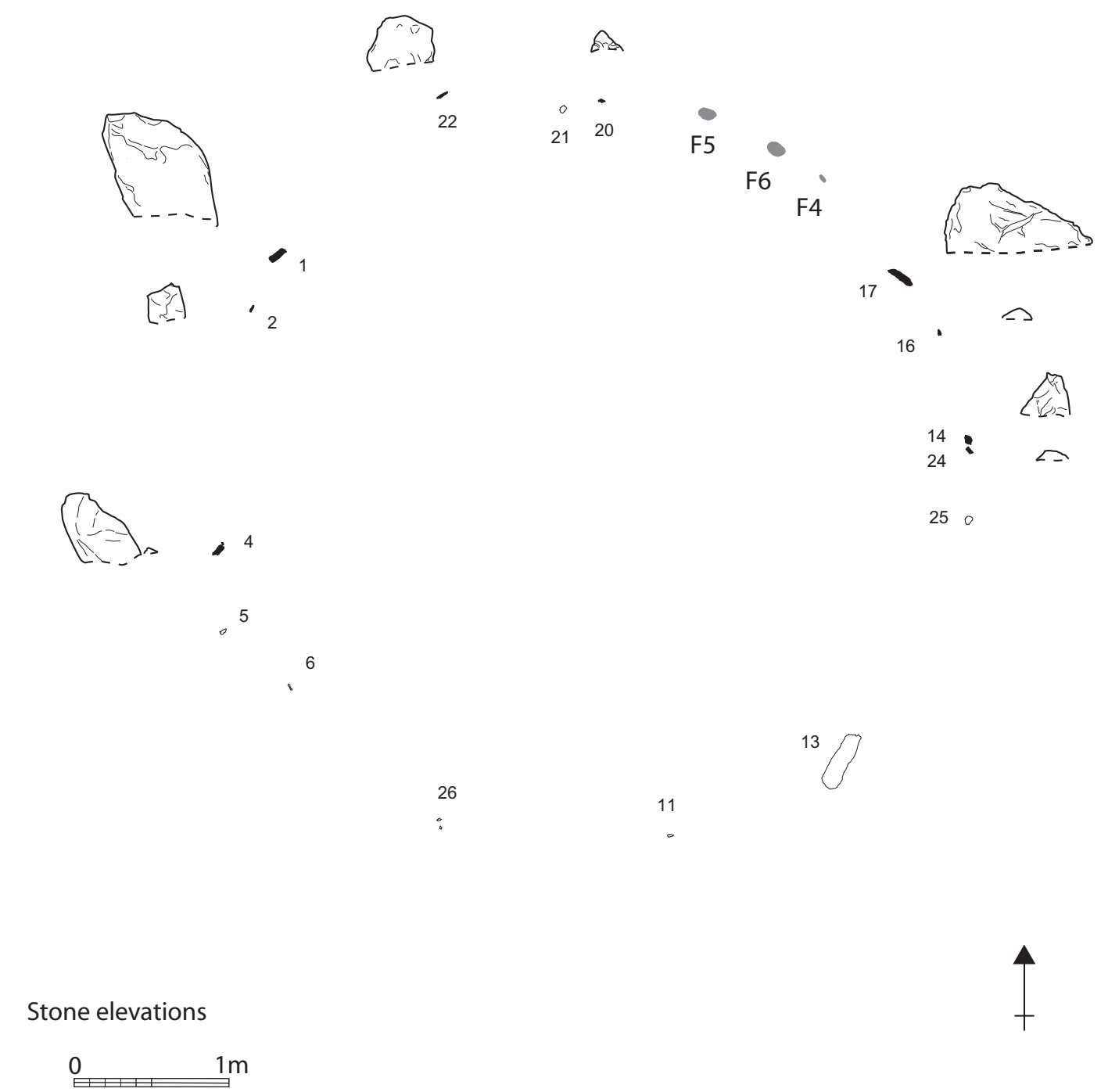

Ground Plan

- standing stone

0

$20 \mathrm{~m}$

- fallen stone

Figure 14

Plan of Porlock Circle.

three notably larger stones (maximum dimension $0.38 \mathrm{~m}$ ), all of which showed evidence of flaking to accentuate their tapering form. The suggestion is of a stone that was intended from the outset to slope rather than sit upright, the difficulty of ensuring such a configuration reflected in the number of accompanying sandstone wedges. Feature 4 took the form of a deep $(0.29 \mathrm{~m})$ 


\section{MARK GILLINGS}

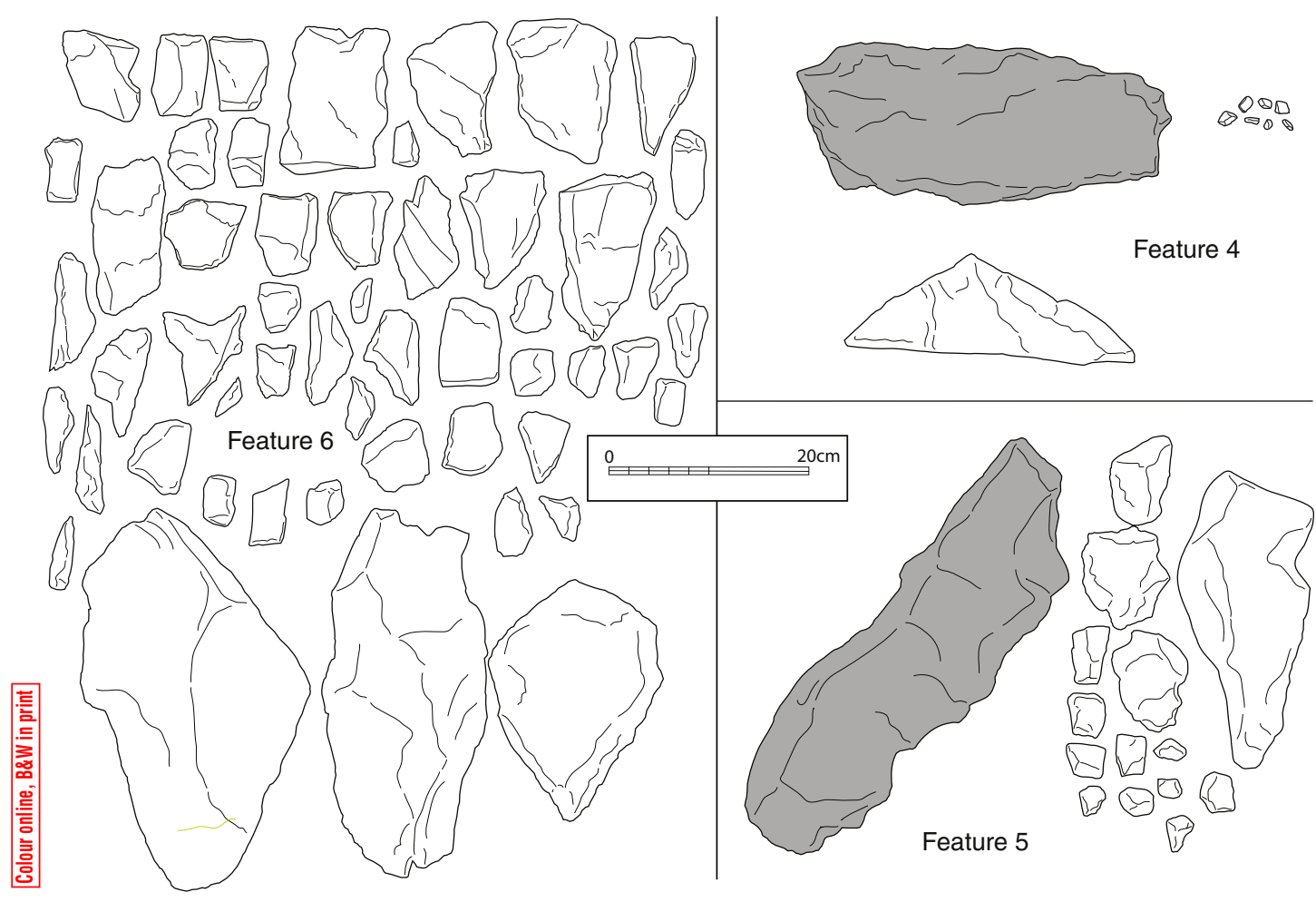

Figure 15

Miniliths (shaded), ‘triggers' and packing stones encountered at Porlock Circle.

sub-circular stonehole with vertical sides containing a tapering stone $(0.28 \mathrm{~m}$ in maximum dimension), with seven smaller pieces of angular sandstone $(0.05-0.1 \mathrm{~m})$ pushed into the lip of the feature. The tapering stone is an example of what are termed 'triggers' in discussions of the Exmoor megaliths, a conspicuous element of the stone settings. Often projecting above the level of the turf alongside the upright, these have been interpreted as a distinctive form of packing stone used to key the uprights in place; stones whose presence is often treated as a proxy for now lost standing stones (Gillings et al. 2010, 298). Some $0.3 \mathrm{~m}$ to the south-west of the hole, lying directly beneath the turf, was a long, flat slab of sandstone $(0.36 \times 0.15 \mathrm{~m})$. Fitting neatly into the excavated stonehole, this represents the original upright and appears to have been carefully withdrawn from the hole and lain adjacent to it $-\mathrm{a}$ form of decommissioning on par with that seen at Furzehill Common I. The stone showed no sign of having been broken or truncated and when in place would have projected only $0.07 \mathrm{~m}$ above the surface of the subsoil (much less above the turf). Feature 5 was marked by a sub-circular stonehole $(0.53 \times 0.43 \mathrm{~m})$ surrounded by a shallow erosion hollow. The sides of the stonehole were vertical, reaching a depth of $0.20 \mathrm{~m}$. A total of 13 packing stones were visible pushed into the sides of the stonehole, and a thin, sharply pointed sandstone trigger $(0.28 \times 0.12 \mathrm{~m})$ lay upon the gently sloping eastern edge. As with Feature 4, placed neatly across one end of the stonehole was the former upright, in this case a thin slab of sandstone $(0.56 \times 0.18 \mathrm{~m})$ corresponding to the original upright which would have stood to a height of $c .0 .36 \mathrm{~m}$. 
JOBNAME: No Job Name PAGE: 22 SESS: 11 OUTPUT: Fri May 29 17:57:38 2015 SUM: 6411F63C

/Xpp84_Wiley/wiley_journal_N-O/OJOA/ojoa_v34_i3/1ojoa_12056

BETYLMANIA? - SMALL STANDING STONES AND THE MEGALITHS OF SOUTH-WEST BRITAIN

SWEATING THE SMALL STUFF

Taken together, the examples discussed above demonstrate that small uprights miniliths - are far from exclusive to specific monument types such as stone rows or circles. Instead, they are encountered, sometimes in remarkable numbers, on a host of different sites and embody a range of practices in terms of stone selection, erection and placement, as well as demonstrating complex configurative associations. As a result, it is difficult to see them as entirely functional and/or in any way mundane, despite the often generalized way in which they have been recorded. The challenge is how to make sense of such features.

One approach is to focus upon the broader trend rather than detail - in this case the selection and erection of deliberately small stones as one of the simple, shared ideas drawn upon by different groups in the context of a range of monumental projects. The variety of ways in which such stones were deployed could then be seen as the outcome of local interpretations and translations of that idea, some, such as the pairing of large and small, having wide currency, others more local. In essence, the assumption is that where we see miniliths, we are essentially seeing the same thing going on in different monuments. This underlies the suggestion by Williams that these small stones reflect a widespread concern with miniaturization that can be detected throughout the second millennium BC. To Williams, small stones were homologues, direct equivalents for larger megaliths, carrying out the same role and afforded the same levels of care and attention in terms of placement and erection (1988, 32-8). This would certainly account for the way in which stones on Exmoor and at Battle Moss were carefully set into place, and would enable us to read the deliberate pairing of stones (and perhaps the recurring iteration of sizes seen in the pit at Rhos-y-Clegyrn) as a direct embodiment of this miniaturizing tendency. If we accept that this shared idea (miniaturization) could be expressed in a variety of ways, then the task is to identify it in practices as varied as the mid-third millennium placement of the betyl stone at Avebury; the deliberate juxtaposition of small/large parallel stone rows seen at Beaghmore; the placement of adjacent uprights at sites such as Rhos-y-Clegyrn; and even the deployment of trigger stones on Exmoor. Indeed it may only be the tendency to treat every stone found in a stonehole other than the megalith as packing that prejudices us against finding more examples. Whilst Williams' work is important in drawing attention to the questions raised by small standing stones, there are many issues with the notion of equivalence that lies at its heart, not least the fact that it fails to address the question why miniaturize in the first place. Nor does it explain those instances of observable patterning between large and small stones which would be redundant if true equivalence pertained (e.g. the Beaghmore stone rows). Whilst some small standing stones do seem to have been erected in much the same way, and in many of the same contexts as traditional megaliths, many do not, even those ostensibly part of the same monumental whole.

An alternative is to focus instead upon the detail, as has been followed here. In the case of the Exmoor stone settings, the excavation of six discrete standing stones revealed at least four distinctive methods for fixing small uprights in place, including stones that are part of the same monument and less than $4.5 \mathrm{~m}$ apart. In some cases the suggestion is of performance; a deliberate, drawn-out process involving the careful preparation of a stonehole or cist and deliberate selection, transportation and placement of packing materials. In others, stone erection seems to have been much more rapid and expedient, raising the question as to whether it was the overall end product that mattered as opposed to the practices that went into its instantiation. This variation in practice is striking and whilst the result - a small standing stone - was the same in 


\section{MARK GILLINGS}

each case, the manner of effecting it was not. We see examples of careful and deliberate stone setting, different only in scale from the practices observed in the case of huge megaliths at sites such as Avebury, alongside practices involving the barest minimum of active intervention. We see stones seemingly fixed in place and others constructed in such a way as to make removal and reinsertion if not routine then at least feasible. What does this represent? Changing practices through time; the preferred approach adopted by different individuals/groups; the pragmatic requirements dictated by specific locations; some combination of the above or other factors entirely?

If we accept that it took place in prehistory, the possibility of deliberate decommissioning is of particular interest. The evidence from Exmoor suggests that in the case of some stones this carried with it the possibility of subsequent re-erection, and we must consider how many of the stones now standing spent part of their lives in abeyance. There is also a tendency to see features such as stone removal and decommissioning solely through the lens of clear (and discrete) phasing and modification, but perhaps this makes an originally progressive and smooth process much too episodic, where small stones might have been going up and down all the time with no meaningful 'break' or pause in the flow, and the final form of the settings less planned than emergent, whether geometric or not (Richards and Wright 2013, 33-9). This sense of a monument very much in motion (Pitts 2001, 21) might also account for the recognized lack of any monumentalizing tendency on Exmoor, insofar as we do not see any evidence of a continuum between small and/or simple settings and larger, more elaborate examples (Gillings et al. 2010, 316). This perceived 'lack' may simply be a consequence of how we elect to characterize the process of monumentalization in the first place. For example, the pace of erection/decommissioning may have increased or decreased despite the component stones staying small. All told, a very different kind of monumental practice where size and grandeur are less important than frequency and dynamism. That this decommissioning of small stones was not restricted to Exmoor is suggested by evidence from Leskernick, although dating is uncertain. Excavations of the terminal of the stone row at the site revealed an episode of careful dismantling that could conceivably have taken place in the Bronze Age, the stone removed and placed across the stonehole (causing minimum damage to the latter) (Bender et al. 1997, 163-4; 2007, 105-8).

Taken as a whole, the picture revealed by excavation is one of complexity and flux. Whilst a number of practices recur - carefully dug stoneholes; cist-like supportive orthostat boxes; the placement of quartz at the edges of uprights; the deliberate decommissioning of settings with the stone placed as if ready for reinsertion; the presence of one or more distinctive wedge-shaped packing stones (termed 'triggers') that rival the size of the upright - they have yet to be encountered in the same combination. Rather than a suite of simple, shared ideas being expressed through a wide variety of practices, i.e. the same thing going on at superficially different monuments, could the converse be true? A host of different ideas and beliefs being expressed through a restricted repertoire of shared practices? Take for instance Porlock Circle and in particular Feature 4. Here we have a stone that would barely have presented at the surface (in common with other, unexcavated stones of the Exmoor settings, circles and stone rows) yet was deliberately sunk some $0.3 \mathrm{~m}$ into the ground in order to effect this appearance. Put simply, there was a deliberate desire to create a small surface projection with larger chunks of stone sunk deeply to ensure only the very top protruded. As a practice, the latter goes beyond merely the selection of small stones and might go some way towards explaining why so many of the very smallest of the Exmoor stones survive. A simple functional interpretation would be that this over-engineering was to ensure that otherwise very fragile, vulnerable stones stayed put, but this 
JOBNAME: No Job Name PAGE: 24 SESS: 11 OUTPUT: Fri May 29 17:57:38 2015 SUM: 6A68E343

/Xpp84_Wiley/wiley_journal_N-O/OJOA/ojoa_v34_i3/1ojoa_12056

BETYLMANIA? - SMALL STANDING STONES AND THE MEGALITHS OF SOUTH-WEST BRITAIN

ignores the fact that all of the Exmoor stones are effectively small and vulnerable yet not all display this iceberg tendency. An alternative is to recognize that this is deliberate, and acknowledge that stones do not always have to go up. What we could be seeing at Porlock is the deliberate inversion of the upright stone ideal - in effect a stone that is 'raised' downwards not up, the small portion projecting above the surface analogous to that usually buried beneath the ground. That active concerns with reversal and inversion had broader currency during the second millennium BC is strongly suggested by sites such as the Holme timber circle (Brennand et al. 2003). This opens up a very different reading of the Porlock Circle, where the surviving fabric hints at alternations between stones set upright and down - in effect two circles interwoven; this perhaps mediated by a third involving the larger sloping stones we now know were deliberately set in angled stoneholes (Fig. 14, stones 1, 4, 17 and Feature 6). Rather than a single circular motif embedding a single metaphorical meaning, we have potentially three, very different circles perhaps coming together to create something far more than the sum of the individual parts; all expressed through the same basic practice of stone erection. This has implications for monuments such as stone rows, where the presence of very small stones is common, not least in questioning archaeological approaches that privilege the visual impact (or presence) of such structures as an interpretative gambit. Take, for example, work on Bodmin, where small, visually unobtrusive stones making up stone rows were 'invigorated' by marking each with a prominent red flag or wrapping them in white plastic (Bender et al. 2007, 100, pls. C2(b), C4(c)). It also draws attention to the setting of miniliths upright in pits (as at Rhos-y-Clegyrn) as well as situations in more traditional megalithic monuments where stoneholes seem unnecessarily deep (e.g. Richards and Wright 2013, 41). It certainly suggests that, contra Clare, we do need to pay careful attention to megaliths that 'barely protrude above the grass'. How many of our stumps may in fact be the 'bases' of inverted megaliths? A different reading also presents itself for instances of precisely the opposite, where conspicuously large megaliths are encountered which sit in extremely shallow stoneholes (Downes et al. 2013, 103-4; Smith 1965, pl. XLb).

Where researchers have identified strong topographic and lunar significance in the organization of monumental structures in other parts of the country (e.g. Bradley 2005), the results from Porlock suggest that a strong chthonic element may also have been in play in the south-west if not more broadly, and as well as looking up (to the heavens) and across (to the surrounding landscape) we also need to consider looking down.

\section{CONCLUSIONS}

As noted in the introduction, throughout Britain and Ireland, the late third and second millennia $\mathrm{BC}$ were characterized by the appearance of a diverse range of stone monuments whose complex biographies and associations render straightforward classification difficult (Roberts 2013, 535-6). In upland areas, these frequently incorporated standing stones - paired, alone, in rows, circles and other geometric configurations (not to mention more erratic arrangements) - in complex relationships with other earthen, wood and stone elements as well as natural features (Bradley 2007, 173-5). One recurrent element of these monumental projects that has escaped sustained critical attention has been the frequent presence of very small upright stones. The current discussion has sought to draw attention to the way in which such features have been effectively written out of our narratives, arguing that far from being mundane or secondary, miniliths represent a further example of the kind of shared belief or idea posited by Bradley and Williams and as a result deserve our critical attention. As the selective review has demonstrated, miniliths occur on 


\section{MARK GILLINGS}

a wide variety of sites spread across the British Isles and whilst several recurring tropes can be identified, they embody considerable variety and variation. In the majority of cases, the cursory way in which such elements have been recorded limits interpretation to questions of pattern, carried out at the scale of the overall monument plan. That further information can be teased out has been demonstrated by the results of recent fieldwork on Exmoor, which argue strongly that identifying small standing stones as a tangible reflection of a widely shared set of beliefs or ideas is merely the first step. For example, the results from the stone settings reveal that surface appearances can be deceptive, a group of otherwise identical standing stones raised and fixed in place using a range of very different practices and techniques. This implies that there may be a further stratum of ideas, materials and practices in play, working at a much finer grain than is usually considered. Similarly, at Porlock Circle the converse seems to be true, where a single set of consistent practices for the raising of stones seems to have been employed to express different, potentially oppositional beliefs. The suggestion here is that rather than a straightforward material manifestation of a simple underlying belief or principle, we are seeing instead a complex interplay and flow between the underlying concepts being expressed and the pool of materials and practices through which this was realized, with the potential for both beliefs and practices to be transformed in the process. Take, for example, the principle of megalithic inversion identified at Porlock Circle that may well have much wider interpretative value.

There are undoubtedly limitations with both the data presented, the theoretical frameworks used to explore them and arguments developed as a result. In the case of Exmoor, the results derive from a piecemeal programme of excavation shaped by management concerns. As a result, with the exception of the decommissioned examples stumbled upon by accident, this has taken the form of very small trenches placed over badly disturbed stones. These tend to be the larger examples and in the majority of cases considerable damage had taken place to the original stoneholes and associated deposits prior to excavation. No stone settings have been fully investigated and the current lack of dating evidence is problematic, not least in establishing the chronology for activities such as stone decommissioning and the tempo of the placement of individual standing stones. Looking to the underlying theoretical frameworks, whilst the work of researchers such as Bradley and Richards has certainly focused attention upon the ways in which different ideas may have been creatively worked through using distinctive materials and practices (as well as situations where the same idea may have been expressed through superficially very different media such as wood, stone, cloth or pigment), there is the nagging worry that the ideas being drawn upon may have been far from 'simple' and anything but stable. There is also a potential danger that rather than seeking to identify specific classes of monument, we will instead distil them down into a series of ideas or motifs and begin to classify those instead. Needless to say, any such tendency needs to be resisted.

Despite these caveats, the discussion has highlighted the enormous interpretative potential presented by small standing stones. To realize these opportunities more fully we need to refine our current approaches to both recording and interpretation. This is not to advocate a form of hyper-empiricism when it comes to the presence of stones or to claim that all stones were equally significant, it is merely to note that our current approaches may have set the bar a little too high.

\section{Acknowledgements}

Thanks to the Exmoor National Park Authority for their support, and Jeremy Taylor for his invaluable feedback on an earlier draft of this paper. 
JOBNAME: No Job Name PAGE: 26 SESS: 11 OUTPUT: Fri May 29 17:57:38 2015 SUM: FA1AD1B2

/Xpp84_Wiley/wiley_journal_N-O/OJOA/ojoa_v34_i3/1ojoa_12056

BETYLMANIA? - SMALL STANDING STONES AND THE MEGALITHS OF SOUTH-WEST BRITAIN

\author{
School of Archaeology and Ancient History \\ University of Leicester \\ University Road \\ Leicester LE1 7RH \\ E-mail:mg41@leicester.ac.uk
}

\title{
REFERENCES
}

Baines, A., Brophy, K. and PanNett, A. 2003: Yarrow Landscape Project/Battle Moss stone rows. Discovery and Excavation in Scotland 4, 94-5.

BENDER, B., HAMILTON, S. and TILLEY, C. 1997: Leskernick: stone worlds; alternative narratives; nested landscapes. Proceedings of the Prehistoric Society 63, 147-78.

BENDER, B., HAmilton, S. and TILley, C. 2007: Stone Worlds: Narrative and Reflexivity in Landscape Archaeology (Walnut Creek).

BENSON, D.G., EVANS, J.G., WILliams, G.H., DARVILL, T. and DAVID, A. 1990: Excavations at Stackpole Warren, Dyfed. Proceedings of the Prehistoric Society 56, 179-245.

BRADLEY, R. 2005: The Moon and the Bonfire: An Investigation of Three Stone Circles in North East Scotland (Edinburgh).

BRADLEY, R. 2007: The Prehistory of Britain and Ireland (Cambridge).

BRADLEY, R. 2011: Stages and Screens: An Investigation of Four Henge Monuments in Northern and North-Eastern Scotland (Edinburgh).

BRENNAND, M., TAYLOR, M., ASHWIN, T., BAYLISS, A., CANTI, M., CHAMBERLAIN, A., FRENCH, C., FRYER, V., GALE, R., GREEN, F., GROVES, C., HALl, A., LINFORD, N., MURPHY, P., ROBINSON, M., WELlS, J. and WILliams, D. 2003: The survey and excavation of a Bronze Age timber circle at Holme-next-the-Sea, Norfolk, 1998-9. Proceedings of the Prehistoric Society 69, 1-84.

BURL, A. 1976: The Stone Circles of the British Isles (New Haven).

BURL, A. 1993: From Carnac to Callanish: The Prehistoric Stone Rows and Avenues of Britain, Ireland and Brittany (New Haven).

CAITHNESS ARCHAEOLOGICAL TRUST 2004: Battle Moss (http://www.caithnessarchaeology.org.uk/ battle_moss.html). Accessed 12 February, 2014.

CHANTER, J.F. and WORTH, R.H. 1905: The rude stone monuments of Exmoor and its borders. Reports and Transactions of the Devonshire Association 37, 375-97.

CHANTER, J.F. and WORTH, R.H. 1906: The rude stone monuments of Exmoor and its borders, Part II. Reports and Transactions of the Devonshire Association 38, 538-52.

CLARE, T. 2010: Megalith size and the implications for our understanding of contemporary society, with particular reference to Cumbria, north-west England. Oxford Journal of Archaeology 29(3), $245-52$.

COONEY, G. 2010: Mundane stone and its meaning in the Neolithic. In O'CONNOR, B., COONEY, G. and CHAPMAN, J. (eds.), Materialitas: Working Stone, Carving Identity (Oxford), 64-74.

DOWNes, J., RICHARDS, C., BROWN, J., CRESSWEll, A., Ellen, R., DAVIES, A., HAll, A., MCCUlLOCH, R., SANDERSON, D. and SIMPSON, I. 2013: Investigating the Great Ring of Brodgar, Orkney. In RICHARDS, C. (ed.), Building the Great Stone Circles of the North (Oxford), 90-118.

EMMETT, D.D. 1979: Stone rows: the traditional view reconsidered. Devon Archaeological Society Proceedings 37, 94-114.

ENGLiSH HeRITAGE 2007: Pastscape (http://www.pastscape.org.uk/hob.aspx?hob_id=433037). Accessed 12 February, 2014.

FOLEY, C. and MACDONAGH, M. 1998: Copney Stone Circles: a County Tyrone enigma. Archaeology Ireland 12(1), 24-8.

GILLINGS, M. 2013: Excavation of the prehistoric landscapes of Lanacombe, Exmoor. Proceedings of the Somerset Archaeological and Natural History Society 156, 41-73.

GILlings, M. forthcoming: Excavation and survey at Porlock Stone Circle, Exmoor. Proceedings of the Somerset Archaeological and Natural History Society.

GILLINGS, M. and TAYLOR, J. 2011a: Excavation and survey at the Exmoor stone settings of Lanacombe I and IV. Proceedings of the Somerset Archaeological and Natural History Society 154, 23-34. 


\section{MARK GILLINGS}

GILLINGS, M. and TAYLOR, J. 2011b: Geophysical survey and excavation at the Exmoor stone setting of Furzehill Common. Devon Archaeological Society Proceedings 69, 1-8.

Gillings, M., POllard, J., WheATley, D.W. and PETERSON, R. 2008: Landscape of the Megaliths: Excavation and Fieldwork on the Avebury Monuments 1997-2003 (Oxford).

GILlings, M., POLLARD, J. and TAYLOR, J. 2010: The miniliths of Exmoor. Proceedings of the Prehistoric Society 76, 297-318.

GRINSELL, L.V. 1970: The Archaeology of Exmoor (Newton Abbot).

HERRING, P. 2008: Stepping out onto the commons: south-western stone rows. In RAINBIRD, P. (ed.), Monuments in the Landscape (Stroud), 79-88.

Johnson, N. and Rose, P. 1994: Bodmin Moor: An Archaeological Survey. Vol. 1: The Human Landscape to $c .1800$ (Swindon).

LEWIS, J.M. 1966: The excavation of four standing-stones in south Wales. Bulletin of the Board of Celtic Studies XXI, 250-64.

LEWIS, J.M. 1975: Excavations at Rhos-y-Clegyrn prehistoric site, St. Nicholas, Pembs. Archaeologia Cambriensis 123, 13-42.

LUCAS, G. 2012: Understanding the Archaeological Record (Cambridge).

MAY, A. MCL. and MITCHELL, G.F. 1953: Neolithic habitation site, stone circles and alignments at Beaghmore, Co. Tyrone. Journal of the Royal Society of Antiquaries of Ireland 83(2), 174-97.

PITTS, M. 2001: Excavating the Sanctuary: new investigations on Overton Hill, Avebury. Wiltshire Archaeological and Natural History Magazine 94, 1-23.

QuinNell, N.V. and DUNN, C.J. 1992: Lithic Monuments within the Exmoor National Park: A New Survey for Management Purposes (Unpublished RCHME survey report).

RICHARDS, C. 2013: Interpreting stone circles. In RICHARDS, C. (ed.), Building the Great Stone Circles of the North (Oxford), 2-30.

RICHARDS, C. and WRIGHT, J. 2013: Monuments in the making: the stone circles of western Scotland. In RICHARDS, C. (ed.), Building the Great Stone Circles of the North (Oxford), 31-61.

RILEY, H. and WILSON-NORTH, R. 2001: The Field Archaeology of Exmoor (Swindon).

ROBERTS, B.W. 2013: Britain and Ireland in the Bronze Age: farmers in the landscape or heroes on the high seas? In FOKKENS, H. and HARDING, A. (eds.), The Oxford Handbook of the European Bronze Age (Oxford), 531-49.

SMITH, I. 1965: Windmill Hill and Avebury (Oxford).

THOM, A.S. 1980: The stone rings of Beaghmore: geometry and astronomy. Ulster Journal of Archaeology $43,15-19$.

TILLEY, C. 2010: Interpreting Landscapes: Geologies, Topographies, Identities (Walnut Creek).

VYNER, B.E. 1977: The excavation of a standing stone at Miskin, Llantrisant, Glamorgan. Archaeologia Cambriensis 126, 17-23.

WARD, A.H. 1983: Excavations around two standing stones on Mynydd Llangyndeyrn, Dyfed. Archaeologia Cambriensis 132, 30-48.

wILLIAMS, G. 1988: The Standing Stones of Wales and South-West England (Oxford, BAR Brit. Ser. 197). 


\section{AUTHOR QUERY FORM}

Dear Author,

During the preparation of your manuscript for publication, the questions listed below have arisen.

Please attend to these matters and return this form with your proof.

Many thanks for your assistance.

\begin{tabular}{|l|l|l|}
\hline $\begin{array}{l}\text { Query } \\
\text { References }\end{array}$ & Query & Remarks \\
\hline 1 & $\begin{array}{l}\text { AUTHOR: Please confirm that given names (red) and surnames/family names } \\
\text { (green) have been identified correctly. }\end{array}$ & \\
\hline 2 & $\begin{array}{l}* \text { AUTHOR: Dryden, H. and Shearer, R.T. 1871 has not been included in the Reference } \\
\text { List, please supply full publication details. }\end{array}$ & \\
\hline
\end{tabular}

Note: The query which is preceded by * is added by Toppan Best-set. 